Machtans, C. S., K. J. Kardynal, and P. A. Smith. 2014. How well do regional or national Breeding Bird Survey data predict songbird population trends at an intact boreal site? Avian Conservation and Ecology 9(1): 5. http://dx.doi.org/10.5751/ACE-00649-090105

Copyright (C) 2014 by the author(s). Published here under license by the Resilience Alliance.

Research Paper

\title{
How well do regional or national Breeding Bird Survey data predict songbird population trends at an intact boreal site?
}

\author{
Craig S. Machtans ${ }^{1}$, Kevin J. Kardynal ${ }^{1}$ and Paul A. Smith ${ }^{2}$ \\ ${ }^{1}$ Environment Canada, Canadian Wildlife Service, ${ }^{2}$ Smith and Associates Ecological Research Ltd.
}

\begin{abstract}
A study to monitor boreal songbird trends was initiated in 1998 in a relatively undisturbed and remote part of the boreal forest in the Northwest Territories, Canada. Eight years of point count data were collected over the 14 years of the study, 1998-2011. Trends were estimated for 50 bird species using generalized linear mixed-effects models, with random effects to account for temporal (repeat sampling within years) and spatial (stations within stands) autocorrelation and variability associated with multiple observers. We tested whether regional and national Breeding Bird Survey (BBS) trends could, on average, predict trends in our study area. Significant increases in our study area outnumbered decreases by 12 species to 6 , an opposite pattern compared to Alberta (6 versus 15 , respectively) and Canada (9 versus 20). Twenty-two species with relatively precise trend estimates (precision to detect $>30 \%$ decline in 10 years; observed $\mathrm{SE} \leq 3.7 \%$ year) showed nonsignificant trends, similar to Alberta (24) and Canada (20). Precision-weighted trends for a sample of 19 species with both reliable trends at our site and small portions of their range covered by BBS in Canada were, on average, more negative for Alberta (1.34\% per year lower) and for Canada (1.15\% per year lower) relative to Fort Liard, though $95 \%$ credible intervals still contained zero. We suggest that part of the differences could be attributable to local resource pulses (insect outbreak). However, we also suggest that the tendency for BBS route coverage to disproportionately sample more southerly, developed areas in the boreal forest could result in BBS trends that are not representative of range-wide trends for species whose range is centred farther north.
\end{abstract}

\section{Les données régionales et nationales du Relevé des oiseaux nicheurs permettent-elles de bien prédire la tendance des populations de passereaux dans un secteur boréal vierge?}

RÉSUMÉ. Une étude visant à suivre la tendance de passereaux boréaux a été amorcée en 1998 dans une partie relativement peu perturbée et isolée de la forêt boréale des Territoires du Nord-Ouest, au Canada. Nous avons échantillonné des points d'écoute pendant 8 des 14 années qu'a duré l'étude (1998-2011). La tendance a été estimée pour 50 espèces d'oiseaux au moyen de modèles linéaires généralisés à effets mixtes, pour lesquels les effets aléatoires ont tenu compte de l'autocorrélation et de la variabilité temporelles (répétabilité intra-annuelle) et spatiales (stations à l'intérieur des peuplements) associées aux observateurs multiples. Nous avons testé si les tendances régionales et nationales du Relevé des oiseaux nicheurs (BBS) pouvaient, en général, prédire les tendances dans notre aire d'étude. Les hausses significatives (12 espèces) dans l'aire d'étude l'ont emporté sur les baisses (6 espèces), une tendance contraire à celle observée en Alberta (respectivement 6 contre 15) et au Canada ( 9 contre 20). Vingt-deux espèces ayant des estimations de tendance relativement précises (suffisantes pour détecter un déclin $>30 \%$ sur 10 ans; erreur-type observée $\leq 3,7 \% /$ an) avaient une tendance non significative, un résultat comparable à ceux de l'Alberta (24) et du Canada (20). La tendance pondérée selon la précision pour un ensemble de 19 espèces ayant une tendance fiable dans notre aire d'étude et une faible portion de leur aire couverte par le BBS au Canada était, en moyenne, plus négative pour l'Alberta (inférieur de 1,34\% par année) et le Canada (inférieur de 1,15\% par année) comparativement à Fort Liard, même si les intervalles de crédibilité de $95 \%$ comprenaient encore des zéros. Nous pensons que ces différences de tendance pourraient être en partie imputables à des pics locaux d'abondance des ressources (épidémie d'insectes). Toutefois, nous sommes également d'avis que la tendance des routes du BBS à être disproportionnellement situées dans des endroits plus au sud et en forêt boréale aménagée pourrait faire en sorte que les tendances provenant du BBS ne sont pas représentatives des tendances dans l'ensemble de l'aire chez les espèces dont l'aire de répartition est centrée plus au nord.

Key Words: boreal forest; generalized linear mixed-effects model; Northwest Territories; observer variability; population trend; spruce budworm

\section{INTRODUCTION}

Conservation and management of songbirds in the boreal forest has reached a turning point. Discussion of declining boreal forest birds in the scientific literature is being paralleled by at-risk designations of many species nationally and provincially. Widespread and once common species like Canada Warbler
(Cardellina canadensis) and Olive-sided Flycatcher (Contopus cooperi) are now listed as threatened under Canada's Species At Risk Act (SARA; S.C. 2002, c. 29), along with other birds with more restricted ranges (e.g., Bicknell's Thrush, Catharus bicknelli, and the percna subspecies of Red Crossbill, Loxia curvirostra). Provinces now have extensive lists of species of concern; $11 \%$ of 
all bird species in Canada are ranked provincially as sensitive, $8 \%$ are at risk, and 3\% may be at risk (CESCC 2011). These assessments contribute to the heightened concern and increasing investment and focus on conservation action in the boreal forest. The significant economic and legal implications of at-risk designations means that the trend data upon which the designations are based must bear close scrutiny.

Listing of the Canada Warbler and Olive-sided Flycatcher was based primarily on negative population trends evident in counts from the Breeding Bird Survey (BBS), with supporting data from Christmas bird counts, provincial bird atlases, checklist programs, or regional monitoring programs (COSEWIC 2007, 2008). Estimates of trends may differ across spatial scales, and understanding the relevance of regional versus range-wide trends is a concern for species' assessments. For example, Holmes and Sherry (2001) and McNulty et al. (2008) showed reasonable agreement of species' trends across scales, in contrast to Blake et al. (1994) and Hagan et al. (1997); all authors were comparing local studies to regional and/or national BBS results. Interpreting trends from a variety of scales and sources becomes yet more difficult when conflating variation attributable to local effects (ecological and sampling), from regional resource pulses (Venier and Holmes 2010), from subdivided populations, or from rangewide population variation that could be caused by a myriad of factors throughout the species' annual migratory cycle (Faaborg et al. 2010). For many boreal forest birds, including the Olive-side Flycatcher, the BBS does not adequately cover large portions of species' ranges (Mo3 designation in Dunn et al. 2005). Earlier studies (Bart et al. 2004, Dunn et al. 2005) defined a threshold of two-thirds of a species' range covered for BBS results to be considered reliable. More recently, Blancher et al. (2009) advocated lower thresholds; $\geq 50 \%$ range covered for a "reliable" trend and $\geq 25 \%$ an "acceptable" trend.

Published literature and conservation planning documents have repeatedly stated the need for better survey coverage of the boreal forest in Canada (e.g., Niemi et al. 1998, Downes et al. 2000, Avian Monitoring Review Steering Committee 2012). The potential bias that can arise from incomplete coverage of the range is a real concern; ecological theory predicts greater variability in abundance at the periphery of a species' range (e.g., Williams et al. 2003) and stable isotope analyses and comparisons of regional trends document that species' populations may not be declining uniformly across their range, e.g., for the Rusty Blackbird (Euphagus carolinus; Machtans et al. 2007, Hobson et al. 2010). Most BBS routes in Canada that are in boreal forest lie at its southern limit (Fig. 1), where development for agriculture, forestry, urban and recreational properties, mining, and oil and gas is common (e.g., Hobson et al. 2002, Lee et al. 2010, http:// www.borealbirds.org/SOBB-Materials/BirdDeclinesFactSheet-BSI. pdf). This overlap of BBS survey coverage with areas of the boreal forest having more habitat removal, change, or disturbance may bias BBS results for species whose ranges extend farther north into areas less impacted by development (Cumming et al. 2001). J. Schieck, D. Huggard, C. Shank, D. Farr, C. Twitchell, and D. Pan 2012 (unpublished data) examined the habitat representativeness of BBS routes for a large portion of boreal Alberta. They found that the BBS-sampled area had a $44.0 \%$ human footprint, versus a $12.9 \%$ overall landscape footprint. Indeed, a new analysis comparing expected to observed densities of landbirds in the boreal plains ecozone of Alberta (ABMI 2012) found that many species had lower than expected abundance in areas impacted by humans. In the same report, consolidated point count data from the Boreal Avian Monitoring program, including BBS data, showed a negative relationship between Olive-sided Flycatcher abundance and both cultivation and urban-industrial development.

Fig. 1. Location of the study area within the Taiga Plains ecozone near Fort Liard, Northwest Territories, Canada (black star). All available Breeding Bird Survey (BBS) routes are shown to indicate their extent within the boreal forest, but many of these routes are not run regularly. Note the prevalence of routes in western Canada that are ostensibly in the boreal forest but are actually in landscapes dominated by agriculture. Other anthropogenic disturbances such as forest harvesting, roads, seismic lines, and oil/gas wells also predominately occur in the southern portion of the boreal ecozone of Canada but are not shown because the scale of plotting extremely exaggerates their actual footprint. The inset map depicts the sample locations in our study area.

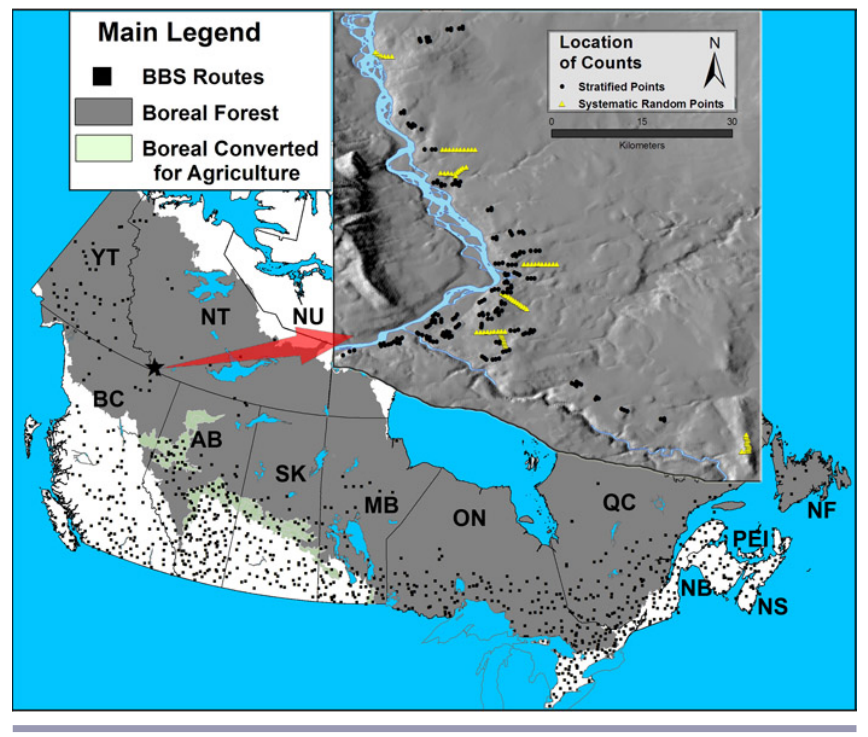

The heavy reliance on BBS results for species' population assessments, coupled with the potential for some degree of bias in its estimates of trend for boreal birds, means that any robust, long term monitoring on the northern breeding grounds of boreal forest songbirds would have considerable value. Unfortunately such independent data for validating regional and national BBS trends are almost nonexistent. Comparisons with the Christmas Bird Count are often not possible because many boreal breeding species winter south of the count areas. On the breeding grounds there are only two studies in Canada that have a current record of bird data from the boreal forest longer than 10 years, not counting double-visit bird atlases, and ours is the only one in a relatively undeveloped part of the boreal forest. The other is the Calling Lake Fragmentation study of Schmiegelow et al. (1997), with continuous data from 1993 (see Boreal Avian Modeling project, http://www.borealbirds.ca). 
We describe the trends in counts of 50 bird species at a site in the southwestern Northwest Territories and contrast these results with regional (Alberta) and Canada-wide trend estimates from the BBS. We tested whether regional and national BBS trends could, on average, predict trends in our study area. If BBS trends are not wholly reflective of true trends of boreal-breeding species, we expect that trends would be, on average, more positive in our less-disturbed site than in neighboring regions with greater disturbance or than national trends if there is a pervasive route by disturbance effect. At the outset we acknowledge that the result of this hypothesis test must be viewed cautiously because our results come from a single site, which may not accurately reflect trends at a larger scale across the northern boreal forest. Therefore, we use this paper and our monitoring study to explore the possibility of geographic bias in trend estimates from the BBS, and encourage further testing by replicating monitoring studies in intact boreal forest or performing innovative analyses of existing data.

\section{STUDY AREA AND METHODS}

This study was located in the Taiga Plains ecozone of the boreal forest in the southwestern Northwest Territories near Fort Liard (Fig. 1; see Machtans and Latour 2003) and encompasses approximately $2600 \mathrm{~km}^{2}$. Habitats include hardwood forest (dominated by Populous tremuloides), mixed-wood forest, coniferous forest (Picea glauca), and forested wetlands (bogs, fens; Picea mariana, Larix laricina). Detailed habitat descriptions and bird-habitat relationships are provided in Machtans and Latour (2003).

Birds were surveyed using points counts, with locations distributed systematically along randomly located transects ( 80 locations, yellow triangles in Fig. 1), or in clusters of three within homogeneous habitat patches (177 locations, black dots in Fig. 1). Individual count locations (plots) were selected to be within 5 $\mathrm{km}$ of the nearest road because they were accessed on foot. Despite some nonrandom elements to plot selection, the proportion of habitat types in our sample was similar to that of the entire study area (mean difference between sample and landscape for eight habitat types was $4 \%$, range $0-9 \%$ derived from a 1:20,000 digital forest inventory). Detailed methods for vegetation sampling are in Machtans and Latour (2003). Our sample included the full range of age classes and canopy tree species in the landscape and, as is the case throughout the region, a majority of the forested habitats sampled were old ( $>120$ years) because of the low fire return interval in the area. Data were collected between 1 to 30 June 1998 - 2002, 2005, 2008, and 2011.

Counts were $10 \mathrm{~min}$ long, unlimited distance, and point count stations were separated by at least $300 \mathrm{~m}$ to reduce double counting of birds (see Machtans and Latour 2003). Most sites were surveyed in all years, but in some years a random sample of plots along transects was not surveyed. All sites selected for surveys within a year were sampled twice, once early in June and once late in June, to capture seasonal differences in bird behavior. Observers were rotated between sites and each observer sampled a site only once within a season, to reduce potential confounding of observer and year effects. Twenty-six observers participated in the study, with all present for $\leq 3$ years except CSM ( 7 of 8 years).

\section{Data analysis}

Generalized linear mixed-effects models (GLMM) were used to assess the trends in counts of 50 bird species for the 14 year sampling period. This method accommodates unbalanced designs, and strengthens inference by using random effects to partition variance into sampling error, trend, and other process variation (Pinheiro and Bates 2000, Bolker et al. 2009, Zuur et al. 2009). We used a log link for Poisson-distributed data (22 species), or a logit link for binomially-distributed data (28 species). For the latter, trends thus reflect trends in presence or absence. However, for these less common species $>98 \%$ of counts were 0 or 1 , so that the interpretation is similar to that for trends in abundance.

Seasonal variation in bird detectability, e.g., song frequency (Best 1981), was accounted for in the models by including the two surveys performed at each station within a year. This random effect of station was nested within a random effect for sampling site (the clusters of three point counts). An additional random effect of observer was included to account for variation in observer ability (Simons et al. 2009). These random effects were included in all models. To assess trends, we evaluated the relative support for models including a constant abundance (or presence) over time, models including a linear year term, and models including both linear and quadratic year terms. For each species, we determined the best supported model on the basis of the lowest AIC (Burnham and Anderson 2002). For Poisson regressions, over-dispersion was tested for each species by dividing the residual deviance by the degrees of freedom for the global model, and corrected with an observation-level random effect where identified as problematic (Breslow 1990). Models were fit using package lme4 (Bates et al. 2011) in program R (R Development Core Team 2012), using the Laplace approximation. We used AIC values as reported by lme4, but acknowledge that development of unbiased measures of Akaike Information in mixed models is an area of ongoing research (Liang et al. 2008, Greven and Kneib 2010).

Regardless of whether or not the best supported model included the quadratic term, we report the linear trend over time, for comparison to the linear trends reported in analyses of BBS data. For these comparisons, we consider models with linear parameter estimates significantly different from zero at $\alpha=0.10$ to show significant trends over time, and also report the SE of the trend parameter to allow for direct interpretation. Trend estimates from this study were compared to those from new analyses of BBS data from Alberta and Canada, 1998-2010, carried out using Hierarchical Bayesian models (Smith et al., in press). Trends were calculated from annual indices that included the full time series of BBS data (1970s to present). Consequently, BBS trend estimates reported here may differ slightly from those reported elsewhere. For these BBS analyses, we consider a species to show significant trends over time when the 90 th $>$ percentile of the credible interval does not overlap zero. Alberta was chosen as the comparison region over the Yukon (good BBS coverage, similar latitude) because many of our birds are eastern species that do not cross the continental divide.

We categorized precision on the basis of whether declines of various magnitudes would have been detected had they occurred $(\alpha \leq 0.1, \beta=0.80)$. The magnitudes of population change used correspond to the thresholds currently in use in Canada by 
COSEWIC; trends with adequate precision to detect a rate of decline equating to $30 \%$ over 10 years $(3.6 \%$ /year) were classified as having good precision ( $\mathrm{SE} \leq 0.022)$, those with precision sufficient to detect a $31-50 \%$ decline (3.7- 6.7\%/year) were classified as having moderate precision ( $\mathrm{SE} \leq 0.041)$, and other estimates were classified as poor. These thresholds relate directly to potential management response: a species may be considered to be At Risk under Species At Risk legislation given declines of $\geq 30 \%$ or $\geq 50 \%$ (depending on circumstance) in 10 years or three generations. We report results from all species with $\geq 10$ detections, present at three or more sites in our study area. However, we acknowledge that results for rare species might be unreliable.

For an overall comparison of trend estimates among spatial scales, we calculated an average difference using a precisionweighted Bayesian approach. We calculated the difference between a species' trend estimate at Fort Liard versus Alberta and Fort Liard versus Canada, and its precision, and used these to estimate the weighted mean difference among trends at the various spatial scales. We specified noninformative priors and used program WinBUGS (Lunn et al. 2000) to calculate the mean differences and their credible intervals.

\section{RESULTS}

\section{Trend analyses}

A total of 39,852 individual birds were detected representing 68 passerine species and one woodpecker species from 3281 point counts across 257 locations in our study area. After removing species with $<10$ detections and those detected in $\leq 3$ sites, 39,760 individuals of 50 species were included in the trend analyses.

The 15 most abundant species accounted for $>80 \%$ of detections, and 15 species had fewer than 100 detections. Trend estimates for many of these latter species had poor precision (Table 1), but are reported here because they represent the only available estimates for this region. A few of those species are much more abundant in the few patches of early successional forest in our study area and roadside verges sampled by the local BBS route (Philadelphia Vireo [Vireo philadelphicus], Alder Flycatcher [Empidonax alnorum], Mourning Warbler [Geothlypis philadelphia], Lincoln's Sparrow [Melospiza lincolnii]). Others such as American Crow [Corvus brachyrhynchos], Varied Thrush [Ixoreus naevius], Orange-crowned Warbler [Oreothlypis celata], Yellow Warbler [Setophaga petechia], Purple Finch [Carpodacus purpureus], and Evening Grosbeak [Coccothraustes vespertinus] are regionally rare. Readers are cautioned that statistically significant trends for species with low sample sizes (Table 1) may be unreliable.

In total, only 6 species showed significant declines in abundance over the sampling period, in comparison to 12 species showing significant increases in abundance. Five of these increasing species were rare in the study area, with fewer than 100 detections. Four of the 12 species with significant increases over the period had a best supported model that included a positive (3 species) or negative ( 1 species) quadratic year term (Table 1). Similarly, the best supported model for 2 species that decreased in abundance over the period included a quadratic year term.

Among the 32 species for which no significant trend was identified in the Fort Liard data, 12 had linear parameter estimates with "good" precision (i.e., able to detect a rate of decline equating to
$30 \%$ over 10 years, equivalent to $38 \%$ over the 14 years of study, had such a decline occurred), 10 had moderate precision (able to detect $50 \%$ decline over 10 years), and 10 had poor precision. For these 32 species, point estimates for the linear year terms were split among declines and increases, with 18 negative and 14 positive (Table 1). For 15 of these 32 species with no significant linear trend in abundance over time, the best supported model included a quadratic year term, with a majority (12 species) peaking in abundance midway during the study period (Table 1).

\section{Comparison with regional and national trends}

The sign of trend estimates from analyses of BBS data for Alberta and all of Canada differed substantially from those from our Fort Liard site. For the same 50 species and over a similar time period (1998 - 2010), BBS results from Alberta and Canada suggested that significant declines outnumbered significant increases 2:1.

The average annual trend difference between regions was compared for the subset of species that had reliable trend estimates, i.e., moderate or good precision, from the Fort Liard data, and were also identified as having insufficient BBS coverage by Dunn et al. (2005). The weighted mean difference in trends (annual \% change) for these 19 species was $-1.16 \%(95 \%$ CI: $-2.96 \%-0.50 \%$ ) for Canada versus Fort Liard, and $-1.34 \%$ (95\% CI: $-3.39 \%-0.67 \%$ ) for Alberta versus Fort Liard (Fig. 2). Although credible intervals for the differences overlap zero, these results suggest that trends were, on average, more positive in Fort Liard versus Alberta or Canada.

Fig. 2. Mean differences of annual trends among regions for 19 species with moderate to high precision from the Fort Liard analysis and identified as having insufficient BBS coverage by Dunn et al. (2005). Error bars represent the 95\% credible intervals for the precision-weighted mean. A negative value indicates that trends at Fort Liard were, on average, more positive.

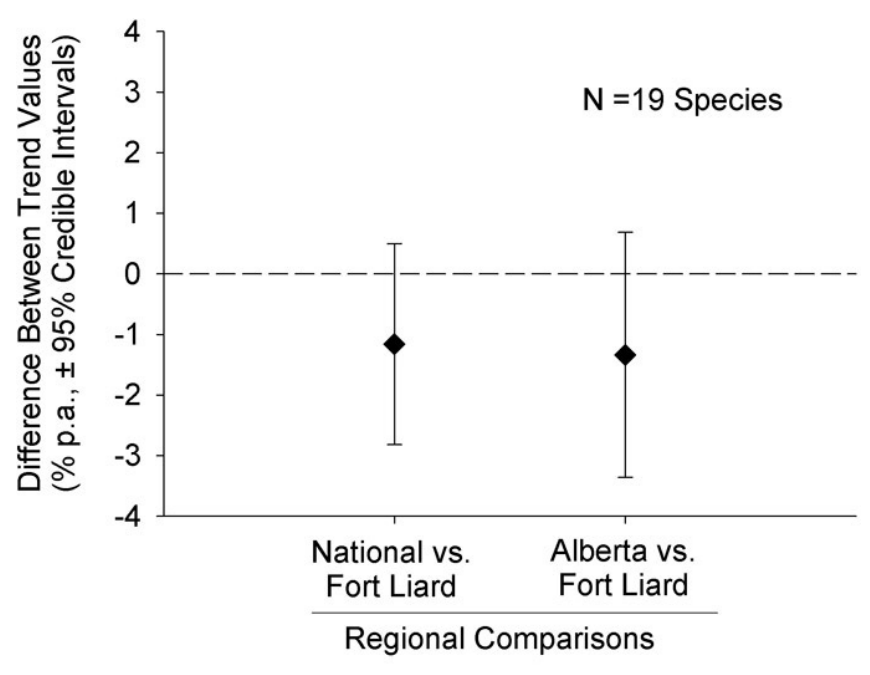

At the level of individual species, trends differed widely for Fort Liard, Alberta, and Canada, including statistically significant 
Table 1. Trend estimates of 50 bird species monitored over 8 sampling occasions from 1998-2011 in a relatively undisturbed landscape near Fort Liard, Northwest Territories. Results from Fort Liard are contrasted with analyses of Breeding Bird Survey (BBS) data from Alberta and all of Canada for 1998-2010 (Adam C. Smith, Environment Canada, unpublished data). For Fort Liard results we report the total number of individuals included in analyses, the estimated linear trend in \% change per year ( \pm SE), and the significance, $\mathrm{P}$, of the linear parameter estimate. We also display the trend indicated by the best supported model (no trend [↔], linear increase $[\uparrow]$ or decrease $[\downarrow]$, or quadratic $[\cap, \cup]$. Where quadratic was the best fit, the best linear model is in parentheses). Trends for Alberta or Canada are described as increases or decreases where the 90th percentile of the credible interval does not overlap 0. Categories for precision are described in the text. The column describing BBS coverage is derived from Appendix 1 in Dunn et al. (2005).

\begin{tabular}{|c|c|c|c|c|c|c|c|c|c|c|}
\hline \multirow[b]{2}{*}{ Common Name } & \multicolumn{9}{|c|}{ Fort Liard } & \multirow[b]{2}{*}{$\begin{array}{c}\text { National BBS } \\
\text { Coverage } \\
\text { Adequate? }\end{array}$} \\
\hline & Scientific Name & n Observed & & $\begin{array}{l}\text { Annt } \\
\text { ge } t\end{array}$ & & $P$ & Trend & $\begin{array}{l}\text { Alberta } \\
\text { Trend }\end{array}$ & $\begin{array}{c}\text { Canada } \\
\text { Trend }\end{array}$ & \\
\hline \multicolumn{11}{|c|}{ Significant negative trend, regardless of precision } \\
\hline Gray Jay & Perisoreus canadensis & 483 & -2.2 & \pm & 1.3 & 0.085 & $\downarrow$ & $\leftrightarrow$ & $\leftrightarrow$ & No \\
\hline Red-breasted Nuthatch & Sitta canadensis & 606 & -3.9 & \pm & 2.1 & 0.057 & $\cup(\downarrow)$ & $\downarrow$ & $\uparrow$ & - \\
\hline American Robin & Turdus migratorius & 470 & -3.4 & \pm & 1.8 & 0.055 & $\downarrow$ & $\leftrightarrow$ & $\leftrightarrow$ & No \\
\hline American Redstart & Setophaga ruticilla & 776 & -5.2 & \pm & 1.5 & 0.000 & $\downarrow$ & $\leftrightarrow$ & $\downarrow$ & No \\
\hline Fox Sparrow & Passerella iliaca & 354 & -9.1 & \pm & 3.5 & 0.006 & $\cap(\downarrow)$ & $\downarrow$ & $\downarrow$ & No \\
\hline Western Tanager & Piranga ludoviciana & 1515 & -3.7 & \pm & 1.0 & 0.000 & $\downarrow$ & $\leftrightarrow$ & $\uparrow$ & - \\
\hline \multicolumn{11}{|c|}{ Significant positive trend, regardless of precision } \\
\hline Alder Flycatcher & Empidonax alnorum & 165 & 6.3 & \pm & 3.0 & 0.041 & $\uparrow$ & $\downarrow$ & $\downarrow$ & No \\
\hline Hammond's Flycatcher & Empidonax hammondii & 93 & 9.0 & \pm & 4.5 & 0.048 & $\uparrow$ & $\leftrightarrow$ & $\leftrightarrow$ & - \\
\hline American Crow & Corvus brachyrhynchos & 36 & 13.9 & \pm & 7.2 & 0.060 & $\uparrow$ & $\downarrow$ & $\leftrightarrow$ & - \\
\hline Common Raven & Corvus corax & 241 & 7.7 & \pm & 2.3 & 0.001 & $\uparrow$ & $\uparrow$ & $\uparrow$ & No \\
\hline Black-capped Chickadee & Poecile atricapillus & 77 & 8.0 & \pm & 4.0 & 0.049 & $\uparrow$ & $\leftrightarrow$ & $\uparrow$ & - \\
\hline Ruby-crowned Kinglet & Regulus calendula & 397 & 7.6 & \pm & 2.2 & 0.001 & $\cap(\uparrow)$ & $\uparrow$ & $\leftrightarrow$ & No \\
\hline Tennessee Warbler & Oreothlypis peregrina & 5093 & 2.1 & \pm & 0.8 & 0.011 & $\uparrow$ & $\leftrightarrow$ & $\leftrightarrow$ & No \\
\hline Mourning Warbler & Geothlypis philadelphia & 54 & 9.2 & \pm & 5.0 & 0.072 & $\uparrow$ & $\downarrow$ & $\downarrow$ & No \\
\hline Common Yellowthroat & Geothlypis trichas & 45 & 15.3 & \pm & 8.2 & 0.071 & $\uparrow$ & $\downarrow$ & $\downarrow$ & - \\
\hline Cape May Warbler & Setophaga tigrina & 248 & 9.9 & \pm & 4.0 & 0.015 & $\cap(\uparrow)$ & $\uparrow$ & $\leftrightarrow$ & - \\
\hline Rose-breasted Grosbeak & Pheucticus ludovicianus & 480 & 3.9 & \pm & 1.8 & 0.027 & $\cap(\uparrow)$ & $\uparrow$ & $\downarrow$ & - \\
\hline White-winged Crossbill & Loxia leucoptera & 2339 & 11.2 & \pm & 1.0 & 0.000 & $\cup(\uparrow)$ & $\leftrightarrow$ & $\leftrightarrow$ & No \\
\hline \multicolumn{11}{|c|}{ No significant trend, good precision } \\
\hline Yellow-bellied Sapsucker & Sphyrapicus varius & 1081 & 0.9 & \pm & 1.4 & 0.535 & $\bigcap(\leftrightarrow)$ & $\uparrow$ & $\uparrow$ & - \\
\hline Least Flycatcher & Empidonax minimus & 440 & -2.6 & \pm & 2.0 & 0.187 & $\cap(\leftrightarrow)$ & $\downarrow$ & $\downarrow$ & No \\
\hline Red-eyed Vireo & Vireo olivaceus & 1653 & -0.1 & \pm & 0.9 & 0.876 & $\leftrightarrow$ & $\downarrow$ & $\uparrow$ & - \\
\hline Swainson's Thrush & Catharus ustulatus & 5110 & 1.0 & \pm & 0.8 & 0.189 & $\cap(\leftrightarrow)$ & $\leftrightarrow$ & $\leftrightarrow$ & No \\
\hline Hermit Thrush & Catharus guttatus & 425 & 1.7 & \pm & 1.8 & 0.360 & $\leftrightarrow$ & $\leftrightarrow$ & $\leftrightarrow$ & No \\
\hline Ovenbird & Seiurus aurocapilla & 2971 & -0.4 & \pm & 0.9 & 0.601 & $\bigcap(\leftrightarrow)$ & $\leftrightarrow$ & $\leftrightarrow$ & - \\
\hline Magnolia Warbler & Setophaga magnolia & 3603 & -1.4 & \pm & 0.9 & 0.106 & $\leftrightarrow$ & $\leftrightarrow$ & $\uparrow$ & No \\
\hline Bay-breasted Warbler & Setophaga castanea & 1031 & 1.6 & \pm & 1.4 & 0.244 & $\bigcap(\leftrightarrow)$ & $\leftrightarrow$ & $\downarrow$ & No \\
\hline Yellow-rumped Warbler & Setophaga coronata & 1841 & -1.2 & \pm & 1.2 & 0.318 & $\leftrightarrow$ & $\leftrightarrow$ & $\leftrightarrow$ & No \\
\hline Canada Warbler & Cardellina canadensis & 569 & -1.2 & \pm & 1.7 & 0.467 & $\leftrightarrow$ & $\leftrightarrow$ & $\downarrow$ & No \\
\hline Chipping Sparrow & Spizella passerina & 2129 & 1.5 & \pm & 0.9 & 0.112 & $\cap(\leftrightarrow)$ & $\downarrow$ & $\downarrow$ & - \\
\hline White-throated Sparrow & Zonotrichia albicollis & 1944 & 1.6 & \pm & 1.0 & 0.122 & $\bigcap(\leftrightarrow)$ & $\downarrow$ & $\downarrow$ & No \\
\hline \multicolumn{11}{|c|}{ No significant trend, moderate precision } \\
\hline Yellow-bellied Flycatcher & Empidonax flaviventris & 265 & -4.0 & \pm & 3.7 & 0.257 & $\leftrightarrow$ & $\leftrightarrow$ & $\downarrow$ & No \\
\hline Blue-headed Vireo & Vireo solitarius & 129 & 2.6 & \pm & 2.9 & 0.371 & $\cap$ & $\leftrightarrow$ & $\uparrow$ & - \\
\hline Warbling Vireo & Vireo gilvus & 310 & 0.9 & \pm & 2.7 & 0.731 & $u$ & $\leftrightarrow$ & $\uparrow$ & - \\
\hline Boreal Chickadee & Poecile hudsonicus & 161 & -3.1 & \pm & 2.8 & 0.248 & $\leftrightarrow$ & $\leftrightarrow$ & $\leftrightarrow$ & No \\
\hline Winter Wren & Troglodytes hiemalis & 317 & 1.6 & \pm & 2.8 & 0.556 & $\cap$ & $\leftrightarrow$ & $\downarrow$ & No \\
\hline Northern Waterthrush & Parkesia noveboracensis & 172 & 1.2 & \pm & 3.5 & 0.730 & $\leftrightarrow$ & $\leftrightarrow$ & $\leftrightarrow$ & No \\
\hline Black-and-white Warbler & Mniotilta varia & 232 & 0.0 & \pm & 2.8 & 0.986 & $\leftrightarrow$ & $\leftrightarrow$ & $\downarrow$ & - \\
\hline Lincoln's Sparrow & Melospiza lincolnii & 96 & 5.3 & \pm & 3.3 & 0.110 & $\leftrightarrow$ & $\downarrow$ & $\downarrow$ & No \\
\hline Dark-eyed Junco & Junco hyemalis & 370 & -2.4 & \pm & 2.6 & 0.356 & $\leftrightarrow$ & $\downarrow$ & $\downarrow$ & - \\
\hline Pine Siskin & Spinus pinus & 832 & 1.1 & \pm & 2.3 & 0.627 & $\cap$ & $\downarrow$ & $\leftrightarrow$ & No \\
\hline
\end{tabular}


No significant trend, poor precision

Western Wood-pewee Contopus sordidulus

Philadelphia Vireo Vireo philadelphicus

Golden-crowned Kinglet Regulus satrapa

Varied Thrush

Bohemian Waxwing

Orange-crowned Warbler

Yellow Warbler

Palm Warbler

Purple Finch

Evening Grosbeak
Ixoreus naevius

Bombycilla garrulus

Oreothlypis celata

Setophaga petechia

Setophaga palmarum

Carpodacus purpureus

Coccothraustes vespertinus

$\begin{array}{ccccc}11 & -11.2 & \pm & 15.0 & 0.392 \\ 16 & -24.5 & \pm & 18.7 & 0.101 \\ 46 & 5.3 & \pm & 5.5 & 0.335 \\ 64 & -4.6 & \pm & 4.8 & 0.323 \\ 55 & -15.9 & \pm & 13.0 & 0.157 \\ 12 & -22.9 & \pm & 22.3 & 0.198 \\ 17 & -2.8 & \pm & 39.1 & 0.932 \\ 337 & -4.0 & \pm & 4.9 & 0.395 \\ 28 & -1.7 & \pm & 6.7 & 0.794 \\ 21 & -2.8 & \pm & 8.2 & 0.719\end{array}$

$\begin{array}{ll}\cap & \downarrow \\ \dot{U} & \leftrightarrow \\ \dot{U} & \leftrightarrow \\ \leftrightarrow & \leftrightarrow \\ \leftrightarrow & \leftrightarrow \\ \leftrightarrow & \uparrow \\ \leftrightarrow & \downarrow \\ \leftrightarrow & \leftrightarrow \\ \leftrightarrow & \leftrightarrow \\ \cap & \leftrightarrow\end{array}$

$\downarrow$
$\leftrightarrow$
$\leftrightarrow$
$\leftrightarrow$
$\leftrightarrow$
$\uparrow$
$\downarrow$
$\leftrightarrow$
$\leftrightarrow$
$\leftrightarrow$

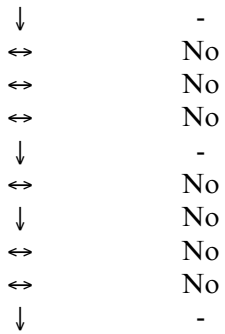

trends differing in direction, i.e., increases vs. declines, among the three spatial scales. For example, counts of the Rose-breasted Grosbeak (Pheucticus ludovicianus) increased significantly over the course of the study at $3.9 \%(95 \% \mathrm{CI}: 0.4 \%-7.5 \%)$ per year in Fort Liard, while the species declined Canada-wide at $-1.3 \%$ per year (95\% CI: $-0.3 \%--2.3 \%$; Fig. 3). Western Tanagers (Piranga ludoviciana) showed the opposite pattern. The species was abundant on surveys at Fort Liard, but declined over the course of the study at $-3.7 \%$ per year $(95 \% \mathrm{CI}$ : $-1.8--5.6)$, in contrast to increases Canada-wide over the same period $(1.1 \%$, 95\% CI: 2.2-0.0; Fig 3; see Appendix 1 for figures for all species).

Bi-plots of annual trends at Fort Liard versus Alberta and Canada are presented in Fig. 4. The bottom right quadrants of the plots highlight birds increasing in Fort Liard but declining in Alberta and Canada, while the top left highlights discordant trends in the other direction. Fort Liard data were poorly correlated with Alberta $(R=0.076, P=0.60)$ and Canada $(R=0.084, P=0.56)$, but Canada and Alberta were significantly, but not strongly correlated $(R=0.351, P=0.01)$. National BBS coverage was deemed to be 'not adequate' for 24 of 40 bird species (Dunn et al. 2005 ) in our study that either had significant trends or moderate to good precision so that large changes in abundance could have been identified, had they occurred (Table 1).

\section{DISCUSSION}

Our comparison of trends of birds in a remote boreal location with trends from regional and national BBS for the same species found disparity between spatial scales that was greater than expected. These results potentially have important implications for the conservation and management of boreal bird species and their habitat, as well as potential consequences for Canada-wide population assessments and monitoring programs. For instance, additional studies in undisturbed portions of the boreal forest would significantly increase our ability to separate breeding ground effects from other portions of the annual cycle (prediction 3 in Rappole and McDonald 1994) and determine where best to make conservation investments.

Comparisons of trend estimates from different spatial scales must be viewed cautiously. One parsimonious explanation includes an expectation on first principles of population dynamics that local, regional, and national trends should differ given the influence of regional drivers, hindering scalability of results. A different explanation is that the preponderance of boreal BBS routes in Canada are located in the southern portion of the boreal forest (Fig. 1) where disturbance is much greater, resulting in a biased BBS population trend for some species, i.e., inadequately sampled
Fig. 3. The estimated annual $\%$ change $(95 \% \mathrm{CI}$ error bars) in counts of Rose-breasted Grosbeaks (Pheucticus ludovicianus) and Western Tanagers (Piranga ludoviciana) at Fort Liard, 1998-2011, versus the trends in counts in Breeding Bird Survey data for Alberta and all of Canada, 1998-2010. The dotted horizontal lines correspond to the annual trend that would halve or double the population in 20 years. Similar graphs for each species analyzed are available in Appendix 1.
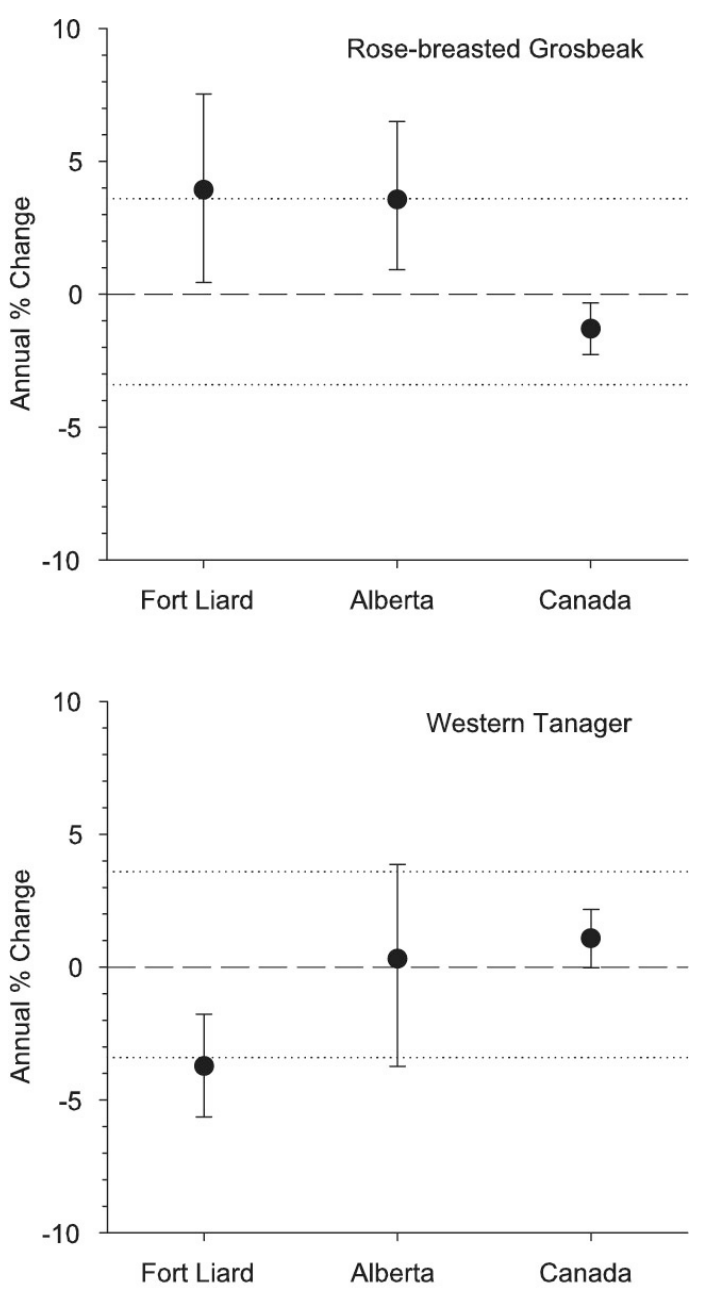
Fig. 4. Bi-plots of annual trend values and associated precision (SE) comparing values in Fort Liard to Alberta (top panel) and Canada (lower panel). Points in the lower right quadrant of the plots have positive trends in Fort Liard and negative trends in the comparison region, while points in the upper left have positive trends in Alberta/Canada and negative trends in Fort Liard. Fort Liard data were poorly correlated with Alberta ( $=0.076, \mathrm{P}=0.60)$ and Canada $(\mathrm{R}=0.084, \mathrm{P}=0.56)$, but Canada and Alberta were significantly, but not strongly correlated $(\mathrm{R}=0.351, \mathrm{P}=0.01)$.
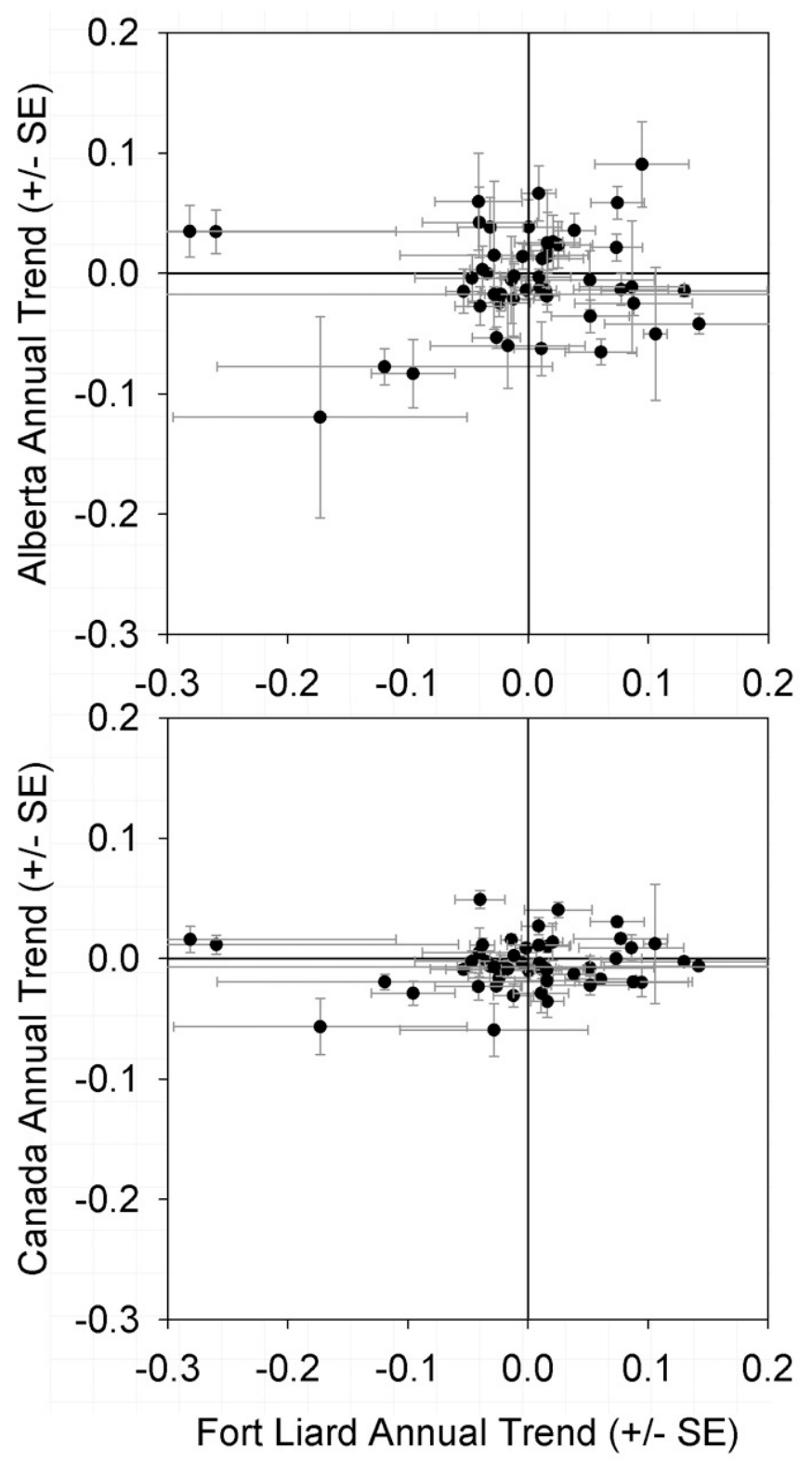

by BBS (Dunn et al. 2005). We find it concerning that trends in our relatively undisturbed area were generally more positive than BBS trends for Canada and Alberta given this potential geographic coverage issue. The explanations for our results are not mutually exclusive and one additional explanation that we do not elaborate on is that our trend estimates are not reflective of trends in regional populations near Fort Liard. We consider this unlikely because of acceptable precision for many species, our analysis methods, and our acceptably representative sampling of the region.

\section{Local habitat issues}

One potential explanation for our results is related to problems with the scalability of local or regional studies, given the spatial extent of processes that are known to affect bird populations in the boreal forest, including habitat change and succession. Several regional studies have documented trends that differ from BBS results (e.g., Linder and Buehler 2005, Howe and Roberts 2005), and each other (Blancher et al. 2009). Trend maps on the United States Geological Survey BBS website (http://www.mbr-pwrc. usgs.gov/bbs/tr2010/trend2010_v1.html) also demonstrate strong regional variation. This regional variability may arise because populations change in response to local drivers, such as habitat disturbance. At Fort Liard, the local habitat change explanation is unlikely. Anthropogenic disturbance in the study area mostly predates sampling or was localized and minimal. Industrial activity peaked in 1995-2000 and has been essentially nonexistent since 2007. Most of that disturbance produced small effects that a regional study like ours would not detect (Machtans 2006). Finally, we collected detailed vegetation data twice during our study, separated by 11 years, and succession was not changing the study stands in any significant way (C. S. Machtans, unpublished data).

\section{Local food/resource issues}

Regional resource pulses and disturbances are known to affect bird populations (Williams and Liebhold 2000, Holmes et al. 2009) and a change in local food resources over the course of our study may also explain our results. However, for several reasons we do not believe this completely explains the tendency for more positive trends at Fort Liard.

First, though there was a severe infestation of spruce budworm (Choristoneura fumiferana) midway through our study, several lines of evidence do not support the outbreak as the primary driver of our results. The outbreak peaked in 2002-2003 and is the parsimonious explanation for the best fit models with quadratic trends for some species (e.g., Bay-breasted Warbler [Setophaga castanea], Cape May Warbler [Setophaga tigrina]). However, Tennessee Warbler (Oreothlypis peregrina), another spruce budworm specialist, increased more than other species during outbreaks, but a linear model was a better fit over the 14 years of monitoring. Populations of these three budworm specialists were all stable or increasing in Alberta (Table 1), in spite of there being no comparable outbreak in Alberta during the study period. If budworm was a primary driver of the trend differences we observed, we would have expected it to be most pronounced for the three classic budworm specialist species, yet it was not. An independent analysis of 1998-2010 western Canada BBS data revealed that regional nonlinear trends are common (D. J. Huggard and C. S. Machtans, unpublished data). For the same 
species as considered here, the majority ( 35 of 50 ) had an AIC weighting $>0.5$ for a quadratic model (compared to linear) in that unpublished BBS analysis.

Second, a resource-pulse signal should already be present in portions of the BBS data, helping dampen the comparative difference with BBS and our study area. Spruce budworm and mountain pine beetle (Dendroctonus ponderosae) usually positively affect the general bird community (Drever et al. 2009, Venier and Holmes 2010) and there are many other places across Canada experiencing insect infestations that positively impact the bird community in the time scales of our comparison. For example, the extent of areas affected by spruce budworm in Alberta has increased steadily over our study period, and is currently increasing in several parts of Canada, though not to epidemic levels (Natural Resources Canada 2012). Regional and national trends should show a positive signal from such outbreaks if indeed they are affecting the underlying regional bird communities as observed by Chan-McLeod et al. (2008) and if the BBS is sampling these areas.

Finally, the effect of the outbreak was not a dominant factor in our data because we had a broad cross-section of species with positive trends and also had budworm-associated species that did not show an overall positive response. Some of the species with no trend or positive trends in our study are not budworm linked, and have been found in previous studies to show no detectable increases in abundance in response to spruce budworm across a range of habitats similar to those in our study (e.g., Lincoln's Sparrow, Rose-breasted Grosbeak, White-winged Crossbill [Loxia leucoptera]; Venier et al. 2009, Venier and Holmes 2010). Species previously shown to have some budworm-linked response but that showed no overall response in our study include the Least Flycatcher [Empidonax minimus], Ovenbird [Seiurus aurocapilla], Magnolia Warbler [Setophaga magnolia], American Redstart [Setophaga ruticilla], and Canada Warbler [Cardellina canadensis].

\section{BBS sampling coverage issues}

A final potential explanation for more positive bird population trends at Fort Liard versus the Alberta and national estimates from BBS is that the distribution of BBS routes in Canada does not sample a representative portion of some species' ranges and resulting trends may be confounded by the overlap of BBS routes with greater anthropogenic disturbance. If this is true, a sample of BBS routes in otherwise intact landscapes or studies like ours would not have the same degree of declines as the BBS data summarized here. The Fort Liard area is relatively remote, with negligible anthropogenic disturbance $(<1 \%$ of entire landscape; Cizek et al. 2002). Therefore, the study area should provide a useful contrast to monitoring studies situated farther south where development is more widespread. Ninety-five percent of oil and gas extraction in Canada is restricted to Bird Conservation Regions (BCR) 6 and 11 (largely in Alberta), settlements and agriculture are vastly more intensive in southern versus northern areas, and there are widely differing impacts of forestry across the country (e.g., Cyr et al. 2009). The degree of habitat change and disturbance in one part of the southern boreal has been correlated with counts from the BBS (Cumming et al. 2001), and the distribution of development in the boreal ecozone broadly coincides with the distribution of most BBS routes (cf. our Fig.
1 with map 2 in Lee et al. 2010). Population trends observed in BBS results may therefore (at least) partially reflect the ongoing habitat disturbance and loss or changes within the portion of the boreal forest sampled by the BBS, but may underrepresent trends from the northern boreal forest. Our results come from a single site and may not reflect trends across larger areas of the northern boreal forest for the reasons already discussed. However, if the results from Fort Liard are representative of other intact, boreal areas, then the relatively more negative trends observed in the national BBS results may reflect that BBS overlaps with disturbed areas more than is representative for Canada's boreal forest as a whole.

There is recent empirical evidence of a development impact to regional bird abundance from boreal Alberta, indicating that the Alberta BBS results should be showing a trend that is partially explained by disturbance on the breeding grounds. The analysis correlated lowered bird abundance to development in the entire boreal portion of Alberta (ABMI 2012). Of the 46 species in common with our study for which they report results, 8 had higher than expected abundance, 11 were as expected, and 26 had lower than expected abundance compared to undisturbed conditions. This ratio of 3:1 species having lower than expected abundance is worse than the ratio for negative to positive trends detected in Alberta by the BBS (Table 2). Development footprints cover $21 \%$ of the boreal plains ecozone of Alberta (AMBI 2012), far greater than the $<1 \%$ documented in our study area and this might reasonably lead to an expectation of the BBS trends being partly driven by local disturbance. However, many BBS routes in the boreal plains of Alberta are in areas dominated by agriculture (Fig. 1) that were cleared long ago. It is possible that losses of boreal forest birds predate the BBS time series, thereby missing a large portion of the development-driven decline but consistent with the low abundances reported by ABMI. When ABMI can report trends in 10-15 years, the comparison with Alberta BBS will be the first broad-scale, independent assessment of the BBS data in boreal Canada.

Table 2. Summary of trends of 50 bird species monitored over 8 sampling occasions during 1998-2011 in a relatively undisturbed landscape near Fort Liard, Northwest Territories, compared with trends for the same 50 species from analyses of Breeding Bird Survey (BBS) data from Alberta and Canada, 1998-2010 (Adam C. Smith, Environment Canada, unpublished data). Precision categories for Fort Liard are described in the text. For the Bayesian BBS analyses, precision categories were assessed as for Fort Liard, but replacing standard errors with half-widths of the credible intervals.

\begin{tabular}{lccc}
\hline \hline \multirow{2}{*}{ Trend and precision } & \multicolumn{3}{c}{ Region } \\
\cline { 2 - 4 } & $\begin{array}{c}\text { Fort } \\
\text { Liard }\end{array}$ & $\begin{array}{c}\text { Alberta } \\
\text { BBS }\end{array}$ & $\begin{array}{c}\text { Canada } \\
\text { BBS }\end{array}$ \\
\hline Significant, negative & 6 & 15 & 20 \\
Significant, positive & 12 & 6 & 9 \\
No trend, good-moderate & 22 & 24 & 20 \\
precision & & & \\
No trend, poor precision & 10 & 5 & 1 \\
\hline
\end{tabular}




\section{CONCLUSION}

The Committee on the Status of Endangered Wildlife in Canada uses a 10-year time period to assess populations of declining species for listing under the Species at Risk Act as noted earlier, and regional sources of trend information are often considered in supplement to BBS. Therefore, comparisons of regional studies to BBS have specific implications for conservation decisions in Canada. Unfortunately, it is often the case that differences between the BBS at various scales and local studies are just as confusing as illuminating. Deriving disturbance covariates for each BBS route in the boreal forest and examining their influence on trend would be particularly useful, but has been seen as prohibitively laborious. The most recent call for additional monitoring in the boreal (Avian Monitoring Review Steering Committee 2012) acknowledges the risks of continuing to rely on the current survey coverage, including erroneous listing of species under the Species at Risk Act. A successful study design for monitoring boreal forest birds needs to have suitable replication both spatially and by management context as previously noted by Carlson and Schmiegelow (2002). Given pragmatic considerations the program would also have to integrate results from disparate methods such as point counts, migration monitoring, and other relevant studies such as was done qualitatively by Blancher et al. (2009). Only then will we be able to make sense of the contrasting sources of information that often raise more questions than they answer. Although our study is unique in its setting and duration, it is a small part of a larger puzzle; ultimately much better cross-study replication is necessary to substantiate conservation actions with increasingly large social and economic consequences.

Responses to this article can be read online at: http://www.ace-eco.org/issues/responses.php/649

\section{Acknowledgments:}

We are very grateful to the 24 field assistants who worked hard to collect all this data, especially to Lindsay Armer. We are also thankful for everyone who has run or currently runs Breeding Bird Survey routes. Mark Drever provided the initial $R$ code and James Hodson assisted in modifying it for our use. Funding for this study was provided primarily by Environment Canada, with additional inkind or financial support from Aboriginal Affairs and Northern Development Canada and the Government of the Northwest Territories. Doug Johnson, Adam Smith, and two anonymous reviewers provided helpful comments on earlier versions of this manuscript.

\section{LITERATURE CITED}

Alberta Biodiversity Monitoring Institute (ABMI). 2012. The status of landbirds in Alberta's boreal plains ecozone-preliminary assessment 2012. ABMI, Edmonton, Alberta, Canada. [online] URL: http://www.abmi.ca/FileDownloadServlet?filename=00067_ABMIBPE-LANDBIRDS_Public_Report-2012.pdf\&dir=REPORTS_UPLOAD

Avian Monitoring Review Steering Committee. 2012. Environment Canada avian monitoring review - final report.
Environment Canada, Ottawa Ontario, Canada. [online] URL: http://publications.gc.ca/site/eng/422608/publication.html

Bart, J., K. P. Burnham, E. H. Dunn, C. M. Francis, and C. J. Ralph. 2004. Goals and strategies for estimating trends in landbird abundance. Journal of Wildlife Management 68:611-626. http://dx.doi.org/10.2193/0022-541X(2004)068[0611:GASFET]2.0. $\mathrm{CO} ; 2$

Bates, D., M. Maechler, and B. Bolker. 2011. Lme4: linear mixedeffects models using S4 classes. R package version 0.999375-42. R Foundation for Statistical Computing, Vienna, Austria. [online] URL: http://CRAN.R-project.org/package $=1$ me 4

Best, L. B. 1981. Seasonal changes in detection of individual bird species. Pages 252-261 in C. J. Ralph and J. M. Scott, editors. Estimating numbers of terrestrial birds. Studies in Avian Biology, No. 6. Allen Press, Lawrence, Kansas, USA.

Blake, J. G., J. M. Hanowski, G. J. Niemi, and P. T. Collins. 1994. Annual variation in bird populations of mixed conifer-northern hardwood forests. Condor 96:381-399. http://dx.doi.org/10.2307/1369322

Blancher, P., R. D. Phoenix, D. S. Badzinski, M. D. Cadman, T. L. Crewe, C. M. Downes, D. Fillman, C. M. Francis, J. Hughes, D. J. T. Hussell, D. Lepage, J. D. McCracken, D. K. McNicol, B. A. Pond, R. K. Ross, R. Russell, L. A. Venier, and R. C. Weeber. 2009. Population trend status of Ontario's forest birds. Forestry Chronicle 85:184-201. http://dx.doi.org/10.5558/tfc85184-2

Bolker, B. M., M. E. Brooks, C. J. Clark, S. W. Geange, J. R. Poulsen, M. H. H. Stevens, and J.-S. S. White. 2009. Generalized linear mixed models: a practical guide for ecology and evolution. Trends in Ecology and Evolution 24:127-135. http://dx.doi. org/10.1016/j.tree.2008.10.008

Breslow, N. 1990. Tests of hypotheses in overdispersed Poisson regression and other quasi-likelihood models. Journal of the American Statistical Association 85:565-571. http://dx.doi. org/10.1080/01621459.1990.10476236

Burnham, K. P., and D. R. Anderson. 2002. Model selection and multimodel inference: a practical information-theoretic approach. Second edition. Springer-Verlag, New York, New York, USA.

Canadian Endangered Species Conservation Council (CESCC). 2011. Wild species 2010: the general status of species in Canada. National General Status Working Group, Ottawa, Ontario, Canada. [online] URL: http://www.wildspecies.ca/wildspecies2010/ default.cfm

Carlson, M., and F. K. A. Schmiegelow. 2002. Cost-effective sampling design applied to large-scale monitoring of boreal birds. Conservation Ecology 6(2): 11. [online] URL: http://www. consecol.org/vol6/iss2/art11

Chan-McLeod, A., X. Zhu, B., Klinkenberg. 2008. Factors affecting the ecological legacy of unsalvaged post-mountain pine beetle stands. Mountain Pine Beetle Working Paper 2008-19. Natural Resources Canada, Canadian Forest Service, Pacific Forestry Centre, Victoria, British Columbia, Canada.

Cizek, P., J. McCullum, and A. Booth. 2002. Fort Liard area cumulative impacts mapping project. Technical report prepared for Canadian Arctic Resources Committee and Canadian Parks and Wilderness Society, Yellowknife, Northwest Territories, 
Canada. [online] URL: http://www.carc.org/sustainable_dev/ Final_Fort_Liard_Technical_Report_May_17_2002.pdf

Committee on the Status of Endangered Wildlife in Canada (COSEWIC). 2007. COSEWIC assessment and status report on the Olive-sided Flycatcher Contopus cooperi in Canada. COSEWIC, Ottawa, Ontario, Canada. [online] URL: http://www. sararegistry.gc.ca/document/default_e.cfm?documentID=1629

Committee on the Status of Endangered Wildlife in Canada (COSEWIC). 2008. COSEWIC assessment and status report on the Canada Warbler (Wilsonia Canadensis) in Canada. COSEWIC, Ottawa, Ontario, Canada. [online] URL:

http://www.sararegistry.gc.ca/document/default_e.cfm?documentID=1591

Cumming, E. E., K. A. Hobson, and S. L. Van Wilgenburg. 2001. Breeding bird declines in the boreal forest fringe of western Canada: insights from long-term BBS routes. Canadian FieldNaturalist 115:425-435.

Cyr, D., S. Gauthier, Y. Bergeron, and C. Carcaillet. 2009. Forest management is driving the eastern North American boreal forest outside its natural range of variability. Frontiers in Ecology and the Environment 7:519-524. http://dx.doi.org/10.1890/080088

Downes, C. M., E. H. Dunn, and C. M. Francis. 2000. Canadian landbird monitoring strategy: monitoring needs and priorities into the new millennium. Partners In Flight-Canada, Ottawa, Ontario, Canada. [online] URL: http://www.ec.gc.ca/mbc-com/ FD5E754F-D977-4123-B6DF-B464893D86C4/strat_e.pdf

Drever, M. C., J. R. Goheen, and K. Martin. 2009. Species-energy theory, pulsed resources, and regulation of avian richness during a mountain pine beetle outbreak. Ecology 90:1095-1105. http:// dx.doi.org/10.1890/08-0575.1

Dunn, E. H., B. L. Altman, J. Bart, C. J. Beardmore, H. Berlanga, P. J. Blancher, G. S. Butcher, D. W. Demarest, R. Dettmers, W. C. Hunter, E. E. Iñigo-Elias, A. O. Panjabi, D. N. Pashley, C. J. Ralph, T. D. Rich, K. V. Rosenberg, C. M. Rustay, J. M. Ruth, and T. C. Will. 2005. High priority needs for range-wide monitoring of North American landbirds. Partners in Flight Technical Series No. 2, Laurel, Maryland, USA. [online] URL: http://www.partnersinflight. org/pubs/ts/02-monitoringneeds.pdf

Faaborg, J., R. T. Holmes, A. D. Anders, K. L. Bildstein, K. M. Dugger, S. A. Gauthreaux, Jr., P. Heglund, K. A. Hobson, A. E. Jahn, D. H. Johnson, S. C. Latta, D. J. Levy, P. P. Marra, C. L. Merkord, E. Nol, S. I. Rothsteen, T. W. Sherry, T. S. Sillet, F. R. Thompson III, and N. Warnock. 2010. Recent advances in understanding migration systems of New World landbirds. Ecological Monographs 80:3-48. http://dx.doi.org/10.1890/09-0395.1

Greven, S., and T. Kneib. 2010. On the behaviour of marginal and conditional AIC in linear mixed models. Biometrika 97:773-789. http://dx.doi.org/10.1093/biomet/asq042

Hagan, J. M., P. S. McKinley, A. L. Meehan, and S. L. Grove. 1997. Diversity and abundance of landbirds in a northeastern industrial forest. Journal of Wildlife Management 61:718-735. http://dx.doi.org/10.2307/3802179

Hobson, K. A., E. M. Bayne, and S. L. Van Wilgenburg. 2002. Large-scale conversion of forest to agriculture in the boreal plains of Saskatchewan. Conservation Biology 16:1530-1541. http://dx. doi.org/10.1046/j.1523-1739.2002.01199.x
Hobson, K. A., R. Greenberg, S. L. Van Wilgenburg, and C. Mettke-Hofmann. 2010. Migratory connectivity in the Rusty Blackbird: isotopic evidence from feathers of historical and contemporary specimens. Condor 112:778-785. http://dx.doi. org/10.1525/cond.2010.100146

Holmes, R. T., and T. W. Sherry. 2001. Thirty-year bird population trends in an unfragmented temperate deciduous forest: importance of habitat change. Auk 118:589-609.

Holmes, S. B., C. J. Sanders, D. Fillman, and D. A. Welsh. 2009. Changes in a forest bird community during an outbreak cycle of the spruce budworm in northwestern Ontario. Bird Populations 9:13-28.

Howe, R. W., and L. J. Roberts. 2005. Sixteen years of habitatbased bird monitoring in the Nicolet National Forest. Pages 963-973 in C. J. Ralph and T. D. Rich, editors. Bird conservation implementation and integration in the Americas: Proceedings of the Third International Partners in Flight Conference. Volume 2. General Technical Report PSW-GTR-191. U.S. Forest Service, Pacific Southwest Research Station, Albany, California, USA.

Lee, P. G., M. Hanneman, and J. D. Gysbers. 2010. Industrialcaused changes to Canada's forest frontier: 1990-2001. Global Forest Watch Canada 10th Anniversary Publication \#10. Edmonton, Alberta, Canada. [online] URL: http://www. globalforestwatch.ca/pubs/2010Anniversary/07Change/Change_HR. pdf

Liang, H., H. Wu, and G. Zou. 2008. A note on conditional AIC for linear mixed-effects models. Biometrika 95:773-778. http://dx. doi.org/10.1093/biomet/asn023

Linder, E. T., and D. A. Buehler. 2005. Analysis of U.S. Forest Service bird point-count monitoring database - implications for designing and implementing avian monitoring. Pages 950-955 in

C. J. Ralph and T. D. Rich, editors. Bird conservation implementation and integration in the Americas: Proceedings of the Third International Partners in Flight Conference. Volume 2. General Technical Report PSW-GTR-191. U.S. Forest Service, Pacific Southwest Research Station, Albany, California, USA.

Lunn, D. J., A. Thomas, N. Best, and D. Spiegelhalter. 2000. WinBUGS - a Bayesian modelling framework: concepts, structure, and extensibility. Statistics and Computing 10:325-337. http://dx.doi.org/10.1023/A:1008929526011

Machtans, C. S. 2006. Songbird response to seismic lines in the western boreal forest: a manipulative experiment. Canadian Journal of Zoology 84:1421-1430. http://dx.doi.org/10.1139/ z06-134

Machtans, C. S., and P. B. Latour. 2003. Boreal forest songbird communities of the Liard Valley, Northwest Territories, Canada. Condor 105:27-44. http://dx.doi.org/10.1650/0010-5422(2003) 105[27:BFSCOT]2.0.CO;2

Machtans, C. S., S. L. Van Wilgenburg, L. A. Armer, and K. A. Hobson. 2007. Retrospective comparison of the occurrence and abundance of Rusty Blackbird in the Mackenzie Valley, Northwest Territories. Avian Conservation and Ecology - Écologie et conservation des oiseaux 2(1): 3. [online] URL: http://www.aceeco.org/vol2/iss 1/art3/ 
McNulty, S. A., S. Droege, and R. D. Masters. 2008. Long-term trends in breeding birds in an old-growth Adirondack forest and the surrounding region. Wilson Journal of Ornithology 120:153-158. http://dx.doi.org/10.1676/07-032.1

Natural Resources Canada. 2012. Spruce budworm. Canadian Forest Service, Natural Resources Canada, Ottawa, Ontario, Canada. [online] URL: http://www.nrcan.gc.ca/forests/insectsdiseases/13383

Niemi, G., J. Hanowski, P. Helle, R. Howe, M. Mönkkönen, L. Venier, and D. Welsh. 1998. Ecological sustainability of birds in boreal systems. Conservation Ecology 2(2): 17 [online] URL: http://www.consecol.org/vol2/iss2/art17/

Pinheiro, J. C., and D. M. Bates. 2000. Mixed-effects models in S and S-Plus. Springer Verlag, New York, New York, USA. http:// dx.doi.org/10.1007/978-1-4419-0318-1

R Development Core Team. 2012. R: A language and environment for statistical computing. $\mathrm{R}$ Foundation for Statistical Computing, Vienna, Austria. ISBN 3-900051-07-0. [online] URL: http://www.R-project.org/

Rappole, J. H., and M. V. McDonald. 1994. Cause and effect in population declines of migratory birds. Auk 111:652-660.

Schmiegelow, F. K. A., C. S. Machtans, and S. J. Hannon. 1997. Are boreal birds resilient to forest fragmentation? An experimental study of short-term community responses. Ecology

78:1914-1932. http://dx.doi.org/10.1890/0012-9658(1997)078 [1914:ABBRTF]2.0.CO;2

Simons, T. R., K. H. Pollock, J. M. Wettroth, M. W. Alldredge, K. Pacifici, and J. Brewster. 2009. Sources of measurement error, misclassification error, and bias in auditory avian point count data. Pages 237-254 in D. L. Thomson, E. G. Cooch, M. J. Conroy, editors. Modeling demographic processes in marked populations. Environmental and Ecological Statistics 3. http://dx.doi. org/10.1007/978-0-387-78151-8_10

Smith, A. C., M.-A. R. Hudson, C. Downes, and C. M. Francis. In press. Estimating Breeding Bird Survey trends and annual indices for Canada: how do the new hierarchical Bayesian estimates differ from previous estimates? Canadian FieldNaturalist.

Venier, L. A., and S. B. Holmes. 2010. A review of the interaction between forest birds and eastern spruce budworm. Environmental Reviews 18:191-207. http://dx.doi.org/10.1139/A10-009

Venier, L. A., J. L. Pearce, D. R. Fillman, D. K. McNicol, and D. A. Welsh. 2009. Effects of spruce budworm (Choristoneura fumiferana (Clem.)) outbreaks on boreal mixed-wood bird communities. Avian Conservation and Ecology - Écologie et conservation des oiseaux 4(1): 3. [online] URL: http://www.aceeco.org/vol4/iss1/art3/

Williams, C. K., A. R. Ives, and R. D. Applegate. 2003. Population dynamics across geographical ranges: time-series analyses of three small game species. Ecology 84:2654-2667. http://dx.doi. org/10.1890/03-0038

Williams, D. W., and A. M. Liebhold. 2000. Spatial synchrony of spruce budworm outbreaks in Eastern North America. Ecology 81:2753-2766. http://dx.doi.org/10.1890/0012-9658(2000)081[2753: SSOSBO]2.0.CO;2

Zuur, A. F., E. N. Ieno, N. J. Walker, A. A. Saveliev, and G. M. Smith. 2009. Mixed effects models and extensions in ecology with $R$. Springer, New York, New York, USA. http://dx.doi. org/10.1007/978-0-387-87458-6
Editor-in-Chief: Keith A.Hobson Subject Editor: Charles M.Francis
Sponsored by the Society of Canadian Ornithologists and Bird Studies Canada Parrainée par la Société des ornithologistes $d u$ Canada et Etudes d'oiseaux Canada

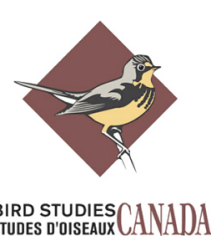


Appendix. Estimated trends in abundance for 50 bird species at three spatial scales, 1998-2011: Fort Liard, NT, in the northern boreal forest, those portions of Alberta covered by the Breeding Bird Survey (see Figure 1), and those portions of Canada covered by the Breeding Bird Survey (see Figure 1). A tabular summary of the trends and their associated precision precedes a graphical presentation of the same data. Trends across years at Fort Liard were estimated with Generalized Linear Mixed Models and error bars depict 95\% confidence intervals of the parameter estimates. Trends for Alberta and Canada were estimated with Hierarchical Bayesian models, and error bars depict $95 \%$ credible intervals. Dashed lines indicate no trend and dotted lines indicate the rate of change required to halve or double the population over 20 years. Species graphs are displayed in taxonomic order.

\begin{tabular}{llrrrrrr} 
& & \multicolumn{4}{c}{ Annual Trend ${ }^{*}$ and Standard Error } \\
\cline { 3 - 7 } Common Name & Scientific Name & Fort Liard & SE (FL) & Alberta & SE (AB) & Canada & SE (CAN) \\
\hline Alder Flycatcher & Empidonax alnorum & 0.0606 & 0.0297 & -0.0654 & 0.0106 & -0.0171 & 0.0039 \\
American Crow & Corvus brachyrhynchos & 0.1301 & 0.0692 & -0.0144 & 0.0048 & -0.0025 & 0.0020 \\
American Redstart & Setophaga ruticilla & -0.0536 & 0.0147 & -0.0149 & 0.0183 & -0.0091 & 0.0040 \\
American Robin & Turdus migratorius & -0.0341 & 0.0178 & -0.0001 & 0.0042 & -0.0025 & 0.0014 \\
Black-and-white Warbler & Setophaga castanea & 0.0005 & 0.0276 & 0.0385 & 0.0229 & -0.0098 & 0.0045 \\
Bay-breasted Warbler & Mniotilta varia & 0.0161 & 0.0138 & 0.0186 & 0.0508 & -0.0356 & 0.0133 \\
Black-capped Chickadee & Poecile atricapillus & 0.0774 & 0.0393 & -0.0134 & 0.0130 & 0.0166 & 0.0043 \\
Blue-headed Vireo & Vireo solitarius & 0.0253 & 0.0283 & 0.0237 & 0.0194 & 0.0405 & 0.0063 \\
Boreal Chickadee & Poecile hudsonicus & -0.0315 & 0.0273 & 0.0384 & 0.0245 & -0.0064 & 0.0130 \\
Bohemian Waxwing & Bombycilla garrulus & -0.1730 & 0.1221 & -0.1195 & 0.0836 & -0.0566 & 0.0234 \\
Canada Warbler & Cardellina canadensis & -0.0121 & 0.0166 & -0.0212 & 0.0307 & -0.0308 & 0.0096 \\
Chipping Sparrow & Spizella passerina & 0.0145 & 0.0091 & -0.0141 & 0.0073 & -0.0079 & 0.0027 \\
Cape May Warbler & Setophaga tigrina & 0.0947 & 0.0391 & 0.0906 & 0.0355 & -0.0198 & 0.0120 \\
Common Raven & Corvus corax & 0.0744 & 0.0223 & 0.0587 & 0.0137 & 0.0305 & 0.0042 \\
Common Yellowthroat & Geothlypis trichas & 0.1422 & 0.0788 & -0.0419 & 0.0083 & -0.0062 & 0.0021 \\
Dark-eyed Junco & Junco hyemalis & -0.0239 & 0.0259 & -0.0245 & 0.0116 & -0.0159 & 0.0050 \\
Evening Grosbeak & Coccothraustes vespertinus & -0.0283 & 0.0784 & 0.0151 & 0.0616 & -0.0594 & 0.0219
\end{tabular}


Annual Trend ${ }^{*}$ and Standard Error

\begin{tabular}{|c|c|c|c|c|c|c|c|}
\hline Common Name & Scientific Name & Fort Liard & SE (FL) & Alberta & $\mathrm{SE}(\mathrm{AB})$ & Canada & SE (CAN) \\
\hline Fox Sparrow & Passerella iliaca & -0.0957 & 0.0348 & -0.0833 & 0.0285 & -0.0287 & 0.0100 \\
\hline Golden-crowned Kinglet & Regulus satrapa & 0.0516 & 0.0535 & -0.0057 & 0.0245 & -0.0077 & 0.0100 \\
\hline Gray Jay & Perisoreus canadensis & -0.0227 & 0.0132 & -0.0173 & 0.0137 & -0.0057 & 0.0088 \\
\hline Hammond's Flycatcher & Empidonax hammondii & 0.0863 & 0.0437 & -0.0114 & 0.0552 & 0.0089 & 0.0107 \\
\hline Hermit Thrush & Catharus guttatus & 0.0164 & 0.0179 & 0.0141 & 0.0115 & 0.0100 & 0.0050 \\
\hline Least Flycatcher & Empidonax minimus & -0.0263 & 0.0199 & -0.0534 & 0.0088 & -0.0229 & 0.0033 \\
\hline Lincoln's Sparrow & Melospiza lincolnii & 0.0518 & 0.0324 & -0.0356 & 0.0137 & -0.0224 & 0.0080 \\
\hline Magnolia Warbler & Setophaga magnolia & -0.0138 & 0.0086 & -0.0054 & 0.0363 & 0.0157 & 0.0045 \\
\hline Mourning Warbler & Geothlypis philadelphia & 0.0880 & 0.0489 & -0.0249 & 0.0103 & -0.0193 & 0.0045 \\
\hline Northern Waterthrush & Parkesia noveboracensis & 0.0118 & 0.0341 & 0.0123 & 0.0154 & -0.0090 & 0.0075 \\
\hline Orange-crowned Warbler & Oreothlypis celata & -0.2596 & 0.2016 & 0.0346 & 0.0180 & 0.0117 & 0.0079 \\
\hline Ovenbird & Seiurus aurocapilla & -0.0045 & 0.0085 & 0.0140 & 0.0104 & -0.0037 & 0.0027 \\
\hline Palm Warbler & Setophaga palmarum & -0.0405 & 0.0476 & 0.0424 & 0.0295 & 0.0051 & 0.0202 \\
\hline Philadelphia Vireo & Vireo philadelphicus & -0.2813 & 0.1713 & 0.0349 & 0.0216 & 0.0159 & 0.0110 \\
\hline Pine Siskin & Spinus pinus & 0.0111 & 0.0229 & -0.0625 & 0.0224 & -0.0288 & 0.0163 \\
\hline Purple Finch & Carpodacus purpureus & -0.0168 & 0.0645 & -0.0600 & 0.0353 & -0.0086 & 0.0068 \\
\hline Rose-breasted Grosbeak & Pheucticus ludovicianus & 0.0385 & 0.0174 & 0.0357 & 0.0142 & -0.0129 & 0.0050 \\
\hline Red-breasted Nuthatch & Sitta canadensis & -0.0399 & 0.0210 & -0.0272 & 0.0158 & 0.0491 & 0.0076 \\
\hline Ruby-crowned Kinglet & Regulus calendula & 0.0734 & 0.0215 & 0.0215 & 0.0113 & 0.0001 & 0.0061 \\
\hline Red-eyed Vireo & Vireo olivaceus & -0.0015 & 0.0093 & -0.0139 & 0.0080 & 0.0087 & 0.0022 \\
\hline Swainson's Thrush & Catharus ustulatus & 0.0098 & 0.0075 & -0.0122 & 0.0097 & -0.0040 & 0.0033 \\
\hline Tennessee Warbler & Oreothlypis peregrina & 0.0206 & 0.0082 & 0.0262 & 0.0223 & 0.0138 & 0.0153 \\
\hline Varied Thrush & Ixoreus naevius & -0.0467 & 0.0473 & -0.0039 & 0.0194 & -0.0024 & 0.0091 \\
\hline Warbling Vireo & Vireo gilvus & 0.0091 & 0.0264 & -0.0030 & 0.0066 & 0.0110 & 0.0042 \\
\hline Western Tanager & Piranga ludoviciana & -0.0379 & 0.0103 & 0.0033 & 0.0194 & 0.0113 & 0.0056 \\
\hline
\end{tabular}




\begin{tabular}{|c|c|c|c|c|c|c|c|}
\hline \multirow[b]{2}{*}{ Common Name } & \multirow[b]{2}{*}{ Scientific Name } & \multicolumn{6}{|c|}{ Annual Trend* and Standard Error } \\
\hline & & Fort Liard & SE (FL) & Alberta & SE $(A B)$ & Canada & SE (CAN) \\
\hline Western Wood-pewee & Contopus sordidulus & -0.1193 & 0.1394 & -0.0776 & 0.0150 & -0.0194 & 0.0063 \\
\hline Winter Wren & Troglodytes hiemalis & 0.0160 & 0.0272 & 0.0254 & 0.0256 & -0.0185 & 0.0058 \\
\hline White-throated Sparrow & Zonotrichia albicollis & 0.0157 & 0.0101 & -0.0190 & 0.0071 & -0.0092 & 0.0025 \\
\hline White-winged Crossbill & Loxia leucoptera & 0.1060 & 0.0098 & -0.0504 & 0.0552 & 0.0123 & 0.0496 \\
\hline Yellow-bellied Flycatcher & Empidonax flaviventris & -0.0412 & 0.0364 & 0.0597 & 0.0402 & -0.0233 & 0.0112 \\
\hline Yellow-bellied Sapsucker & Sphyrapicus varius & 0.0089 & 0.0143 & 0.0665 & 0.0230 & 0.0270 & 0.0072 \\
\hline Yellow-rumped Warbler & Setophaga coronata & -0.0117 & 0.0117 & -0.0020 & 0.0097 & 0.0025 & 0.0037 \\
\hline Yellow Warbler & Setophaga petechia & -0.0282 & 0.3297 & -0.0175 & 0.0061 & -0.0069 & 0.0026 \\
\hline
\end{tabular}

*multiply by 100 to get annual percent change for BBS data, use (EXP(value)-1)x100 for Fort Liard parameter estimates. 

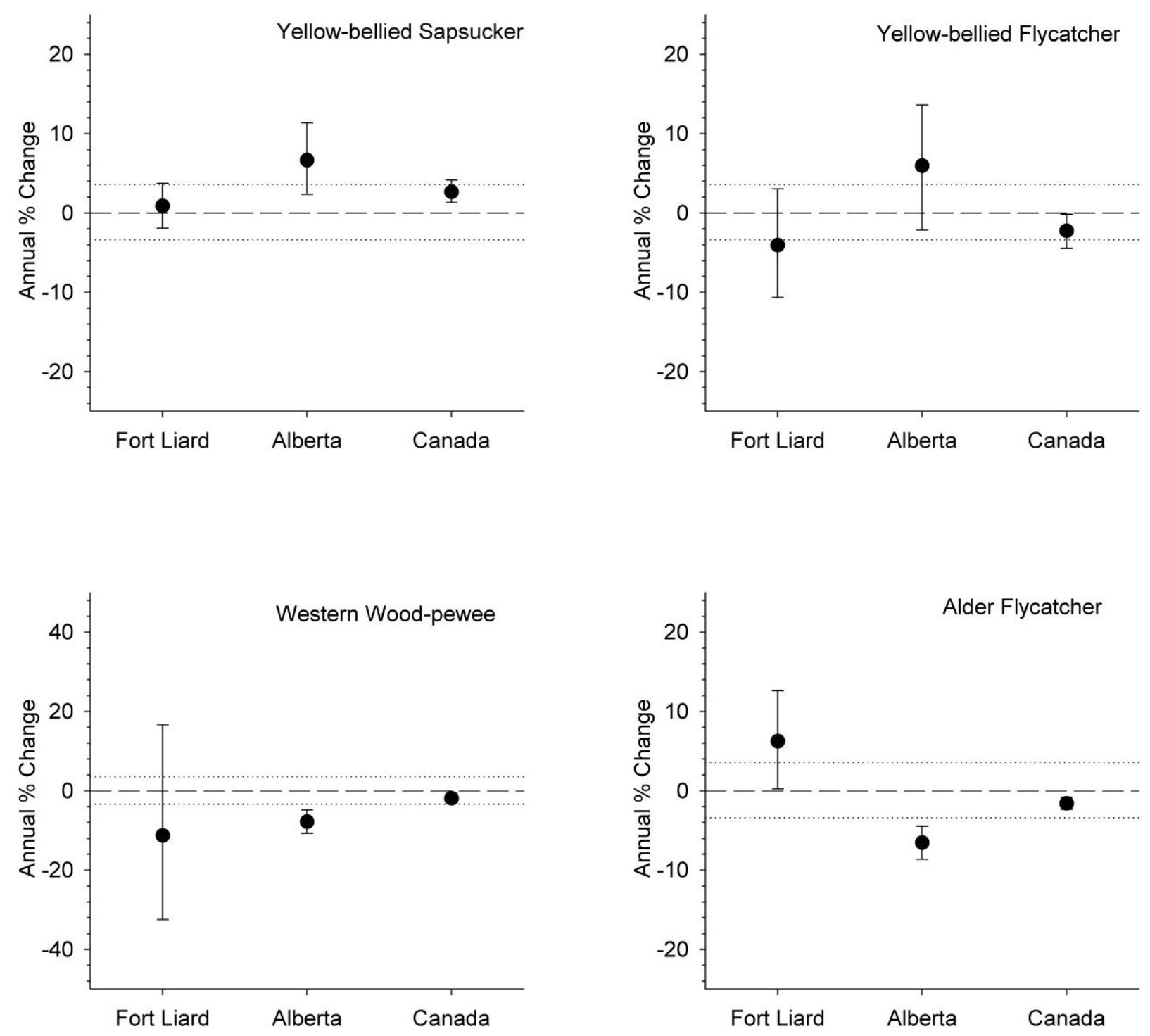

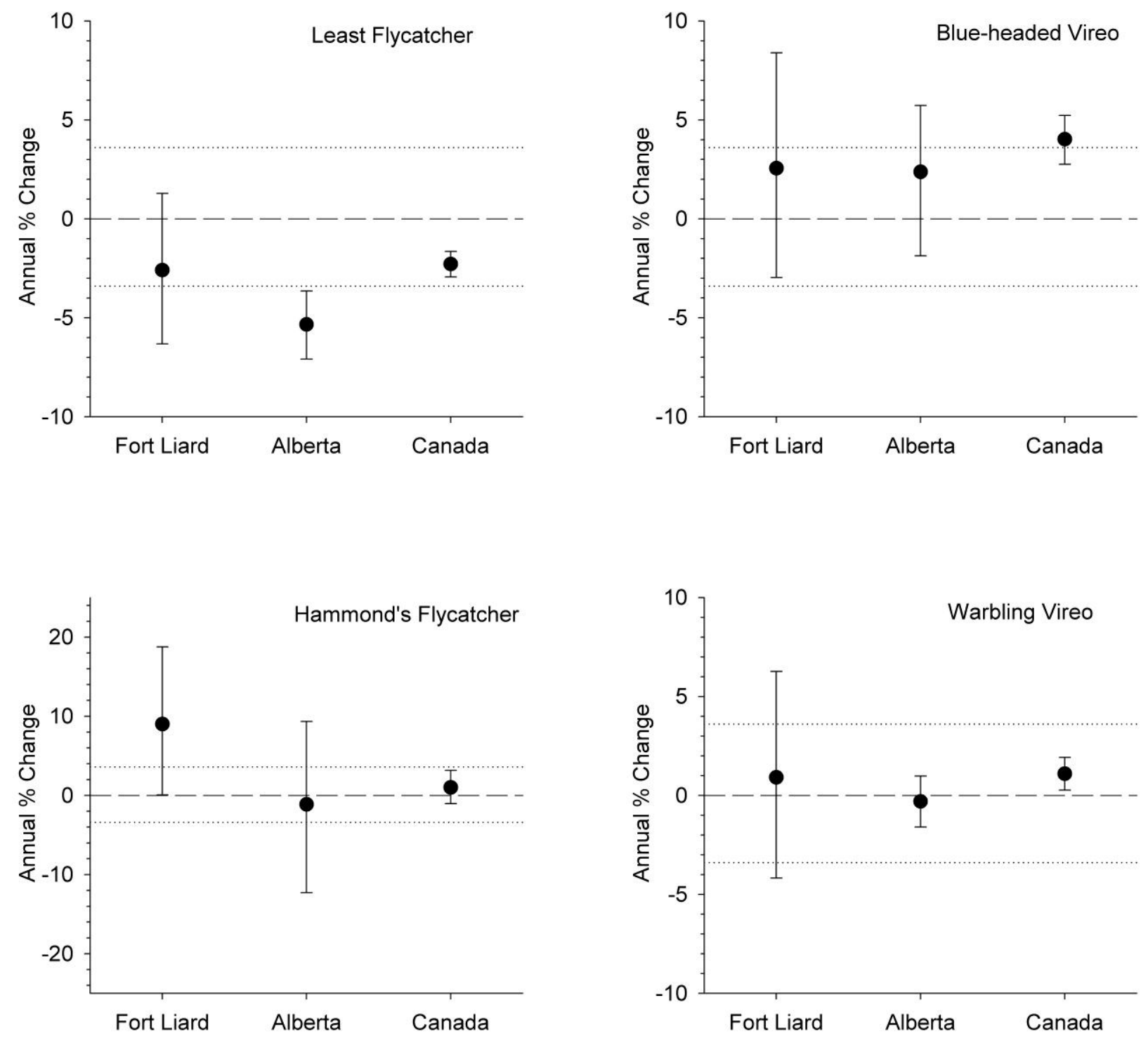

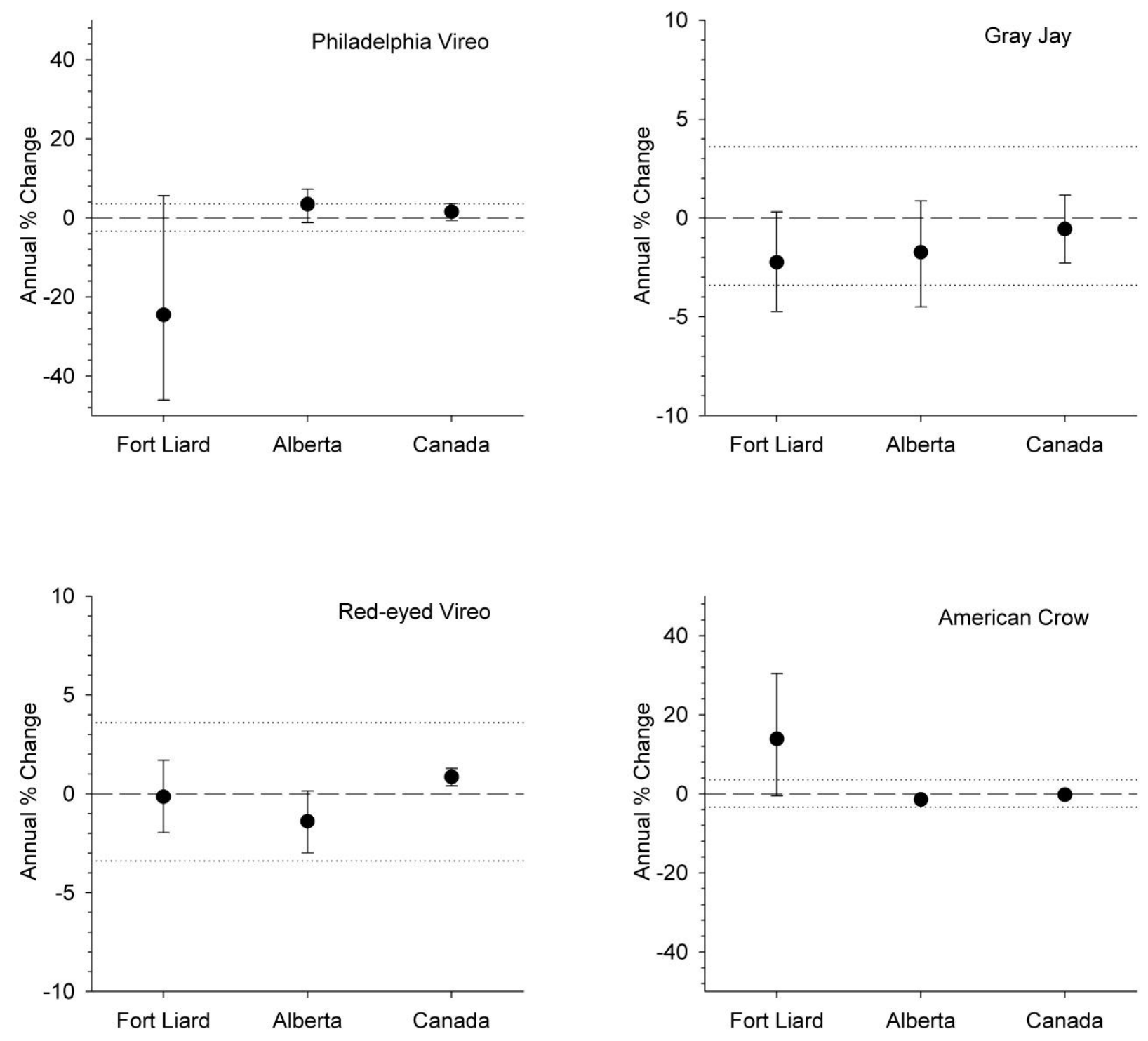

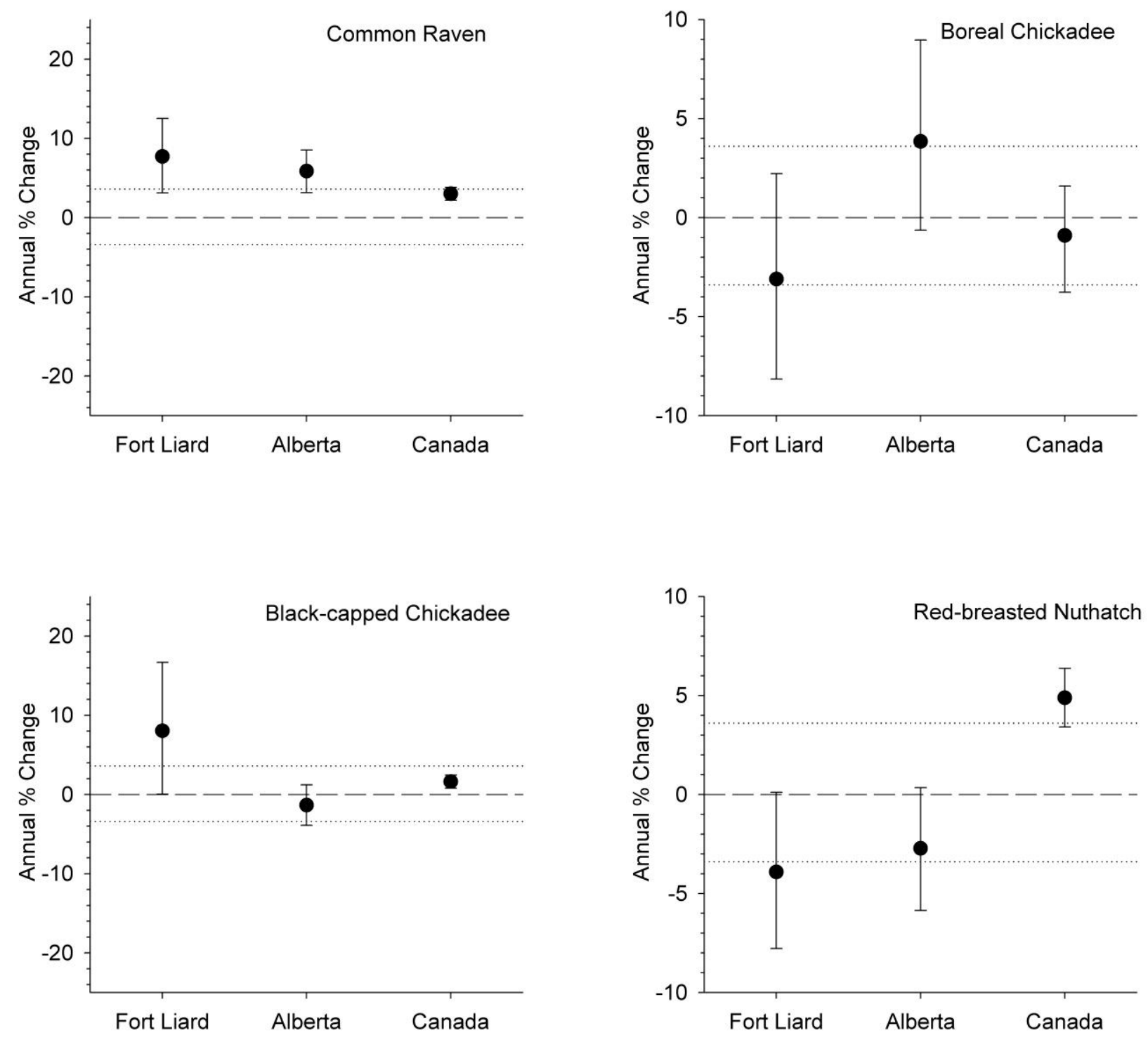

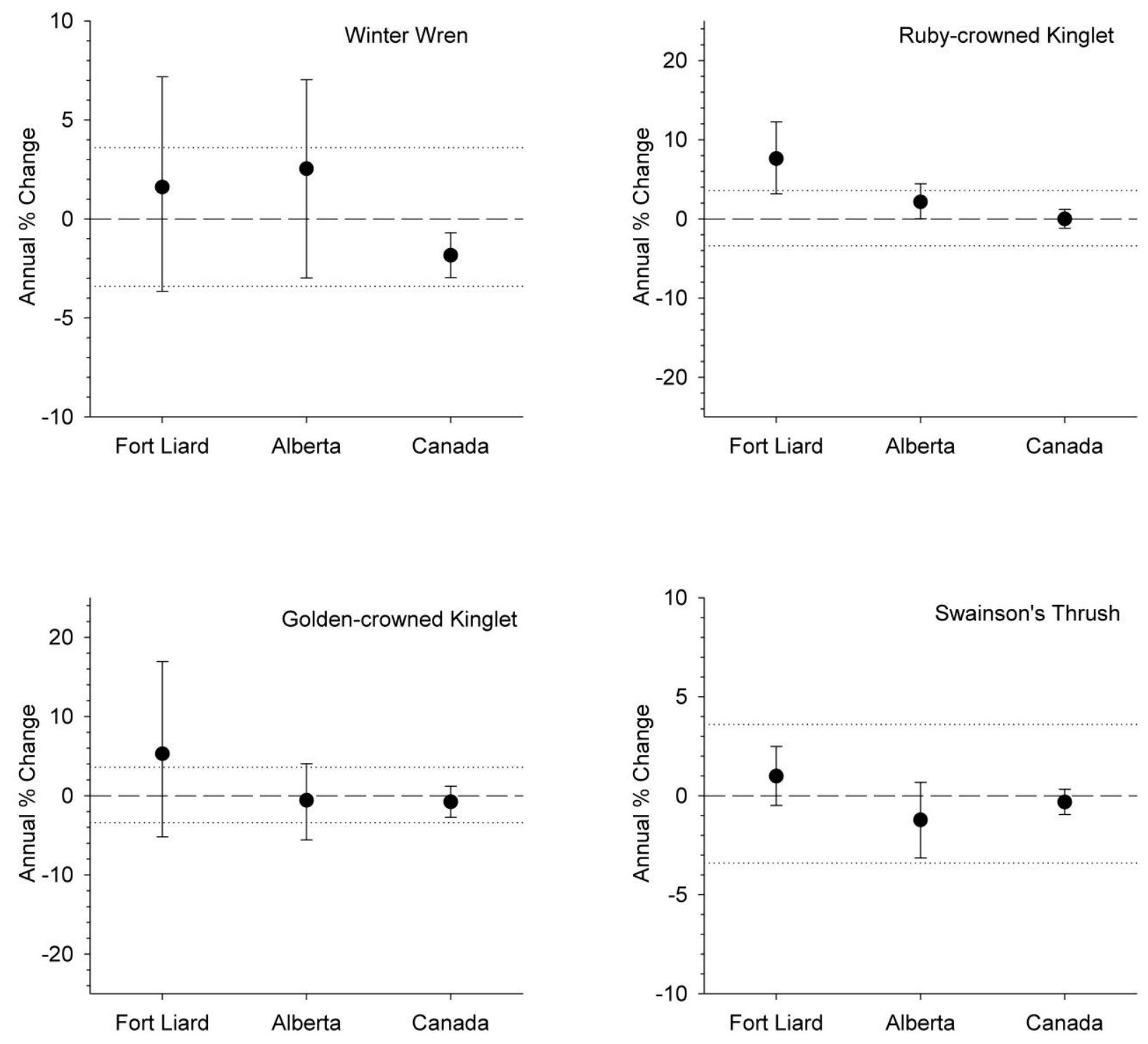

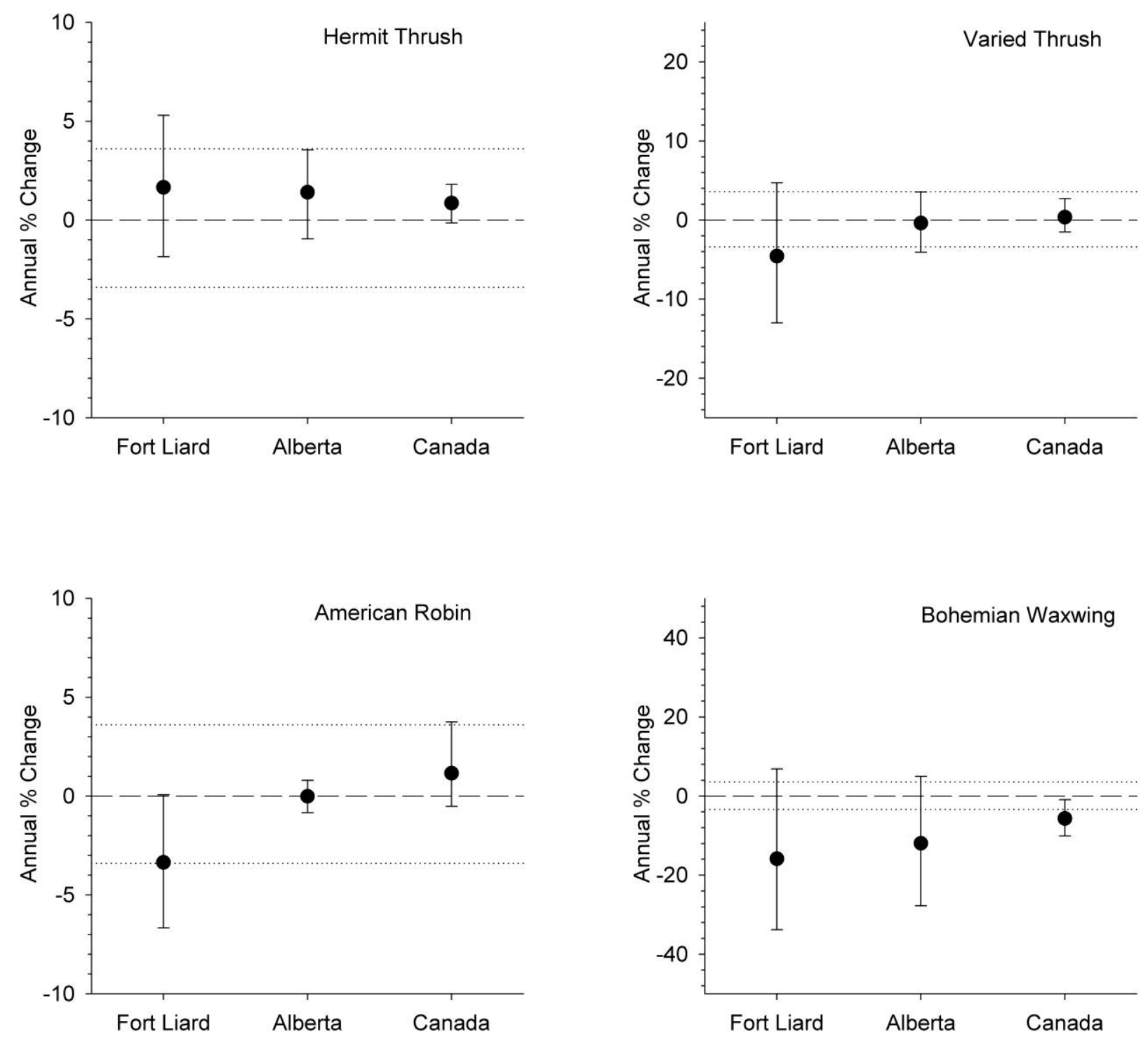

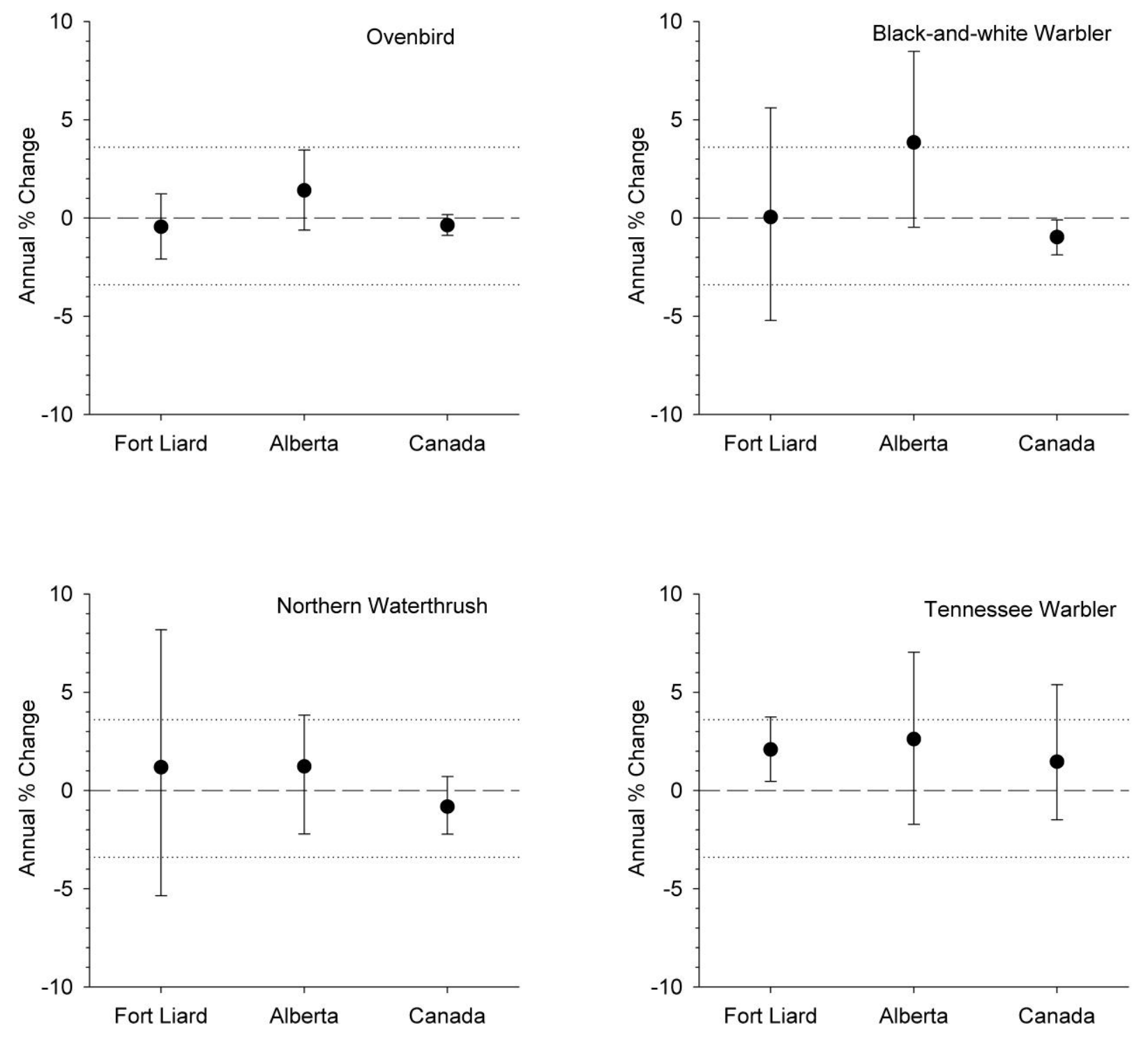

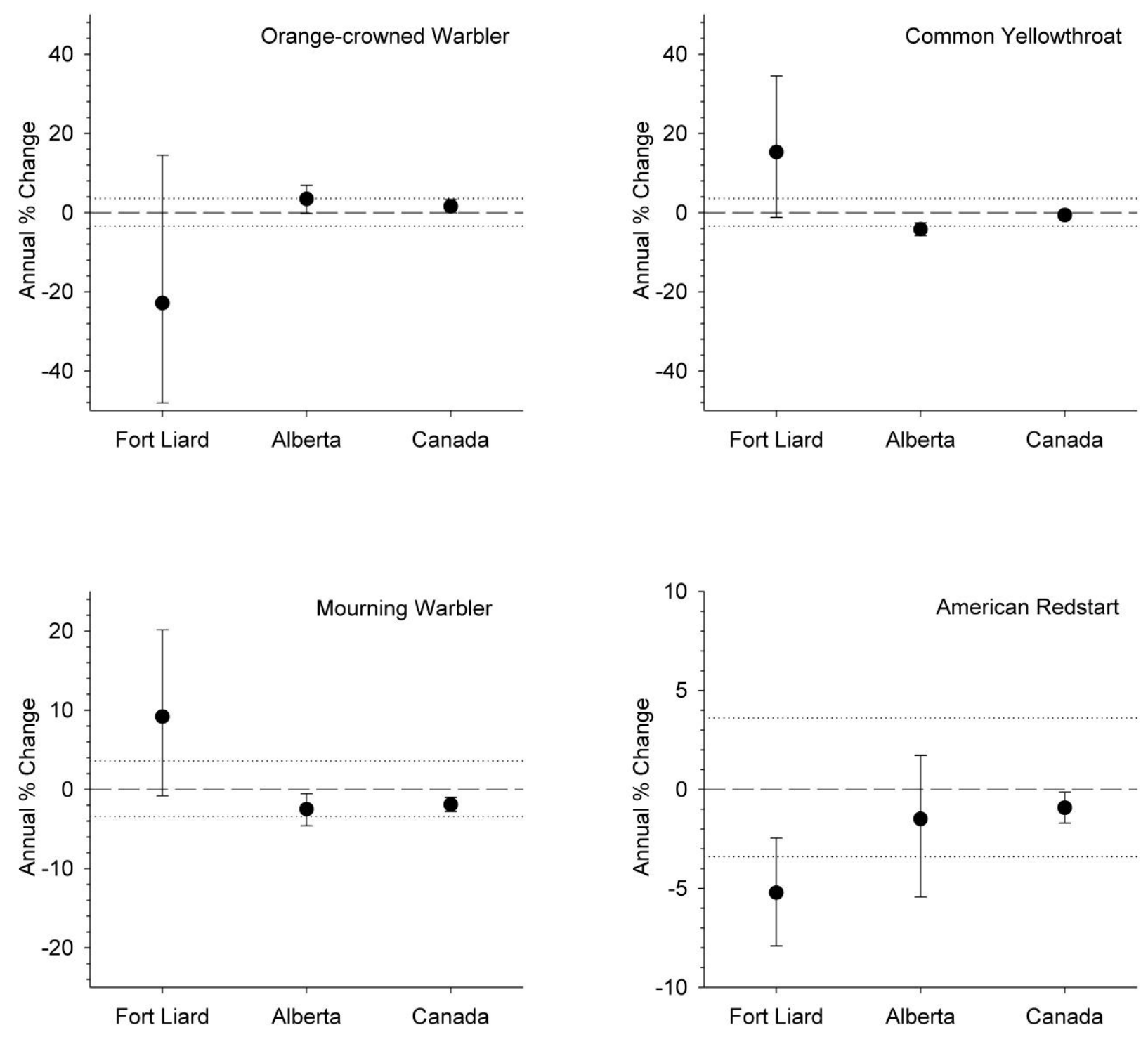

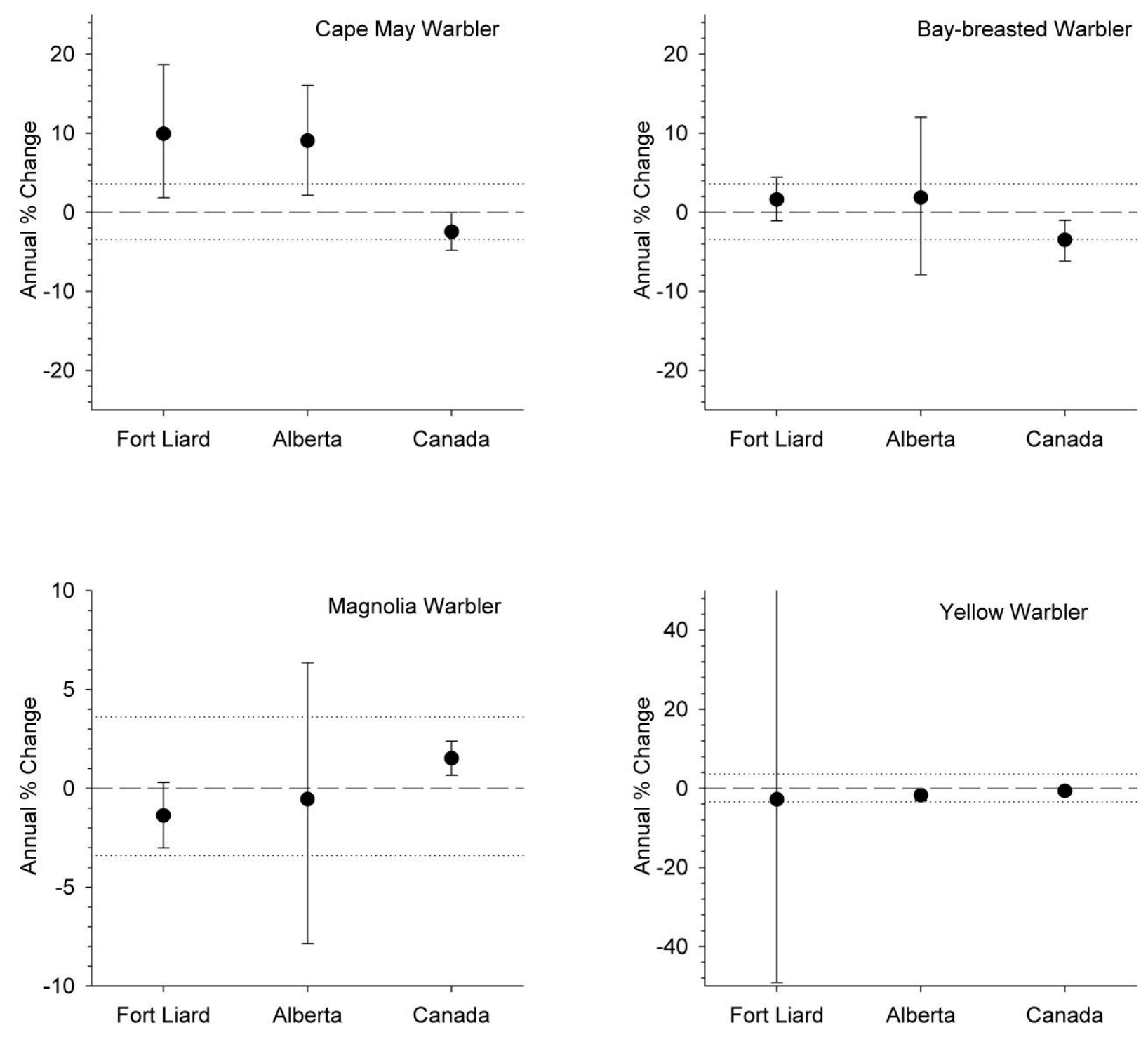

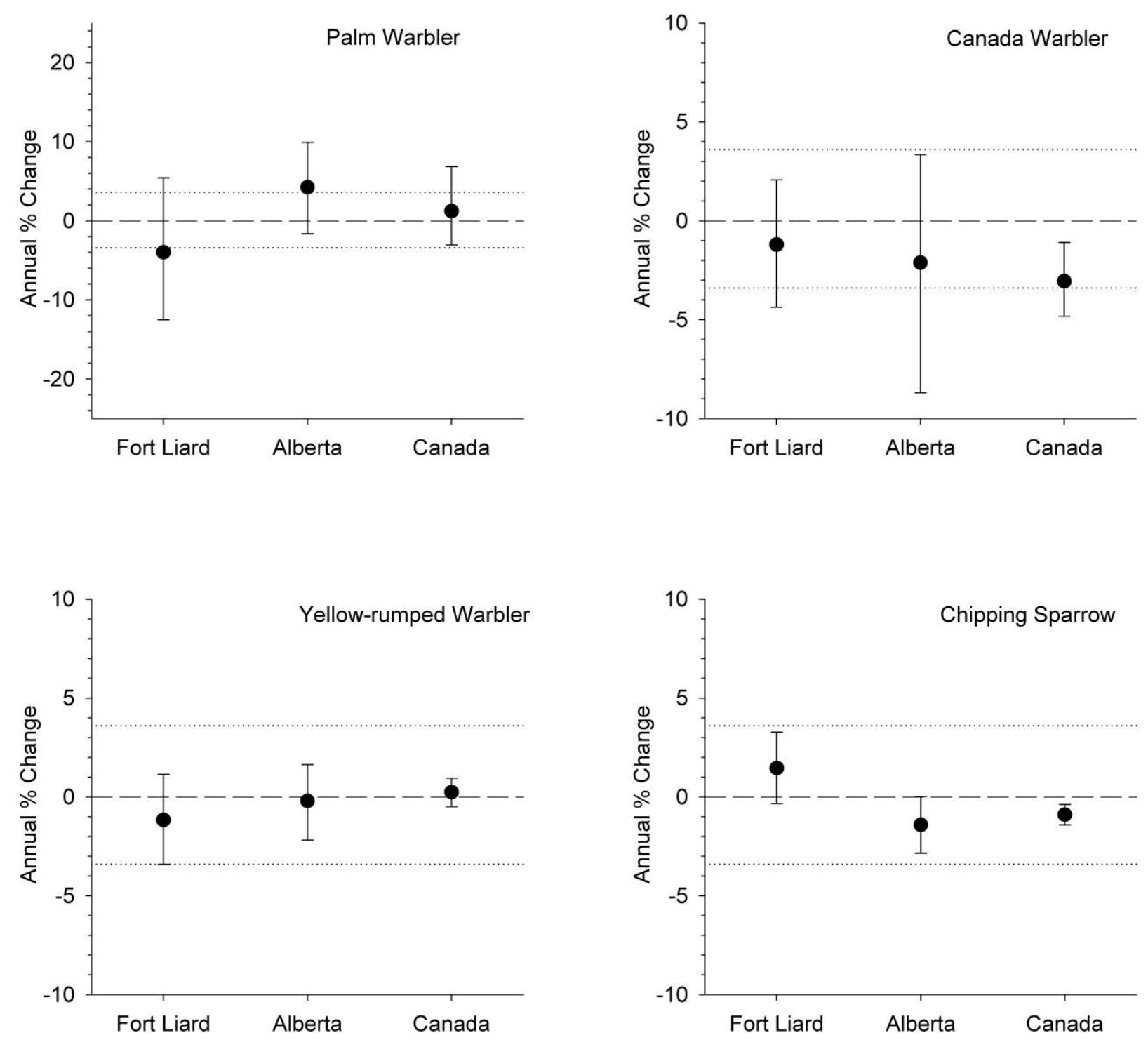

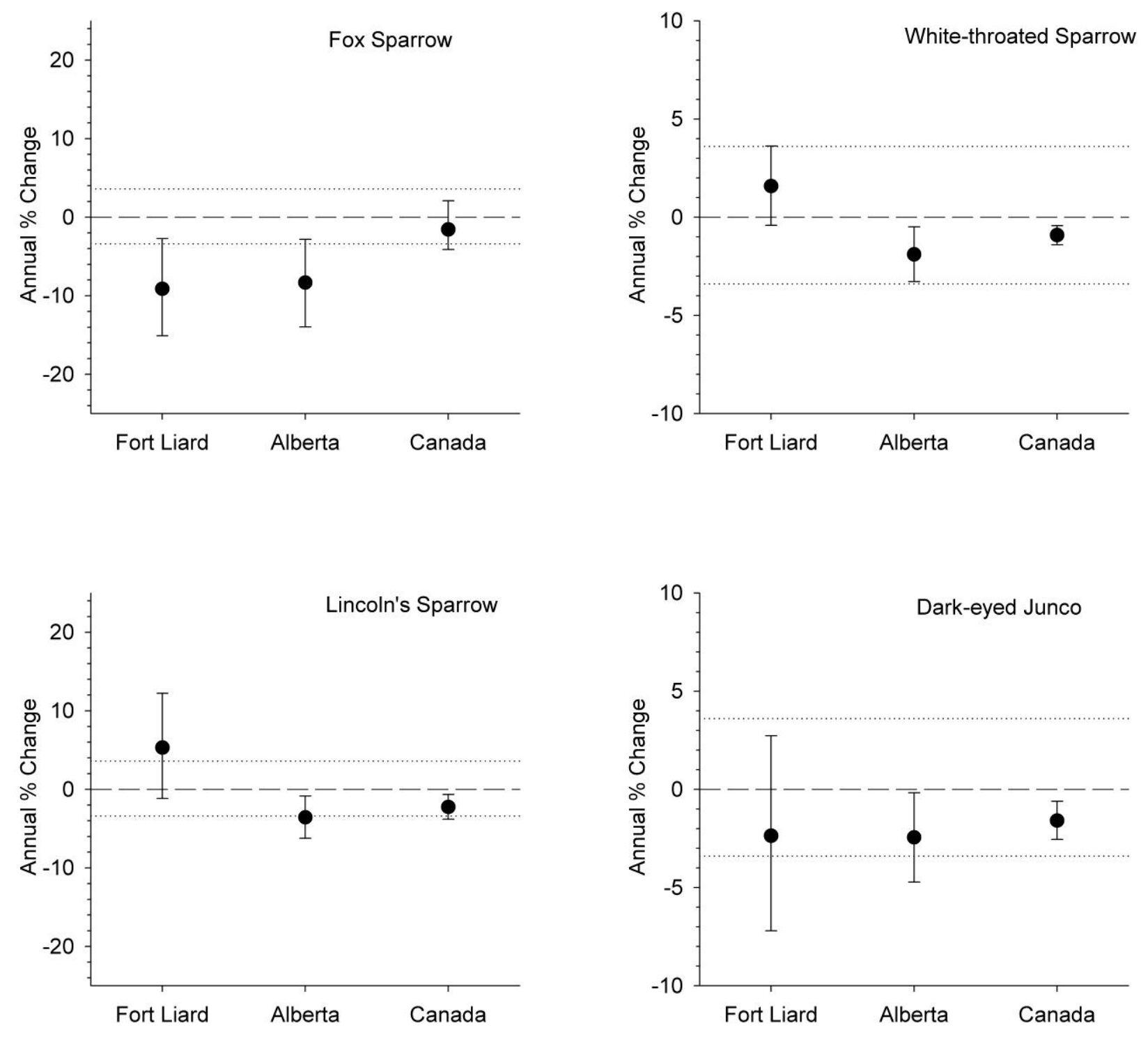

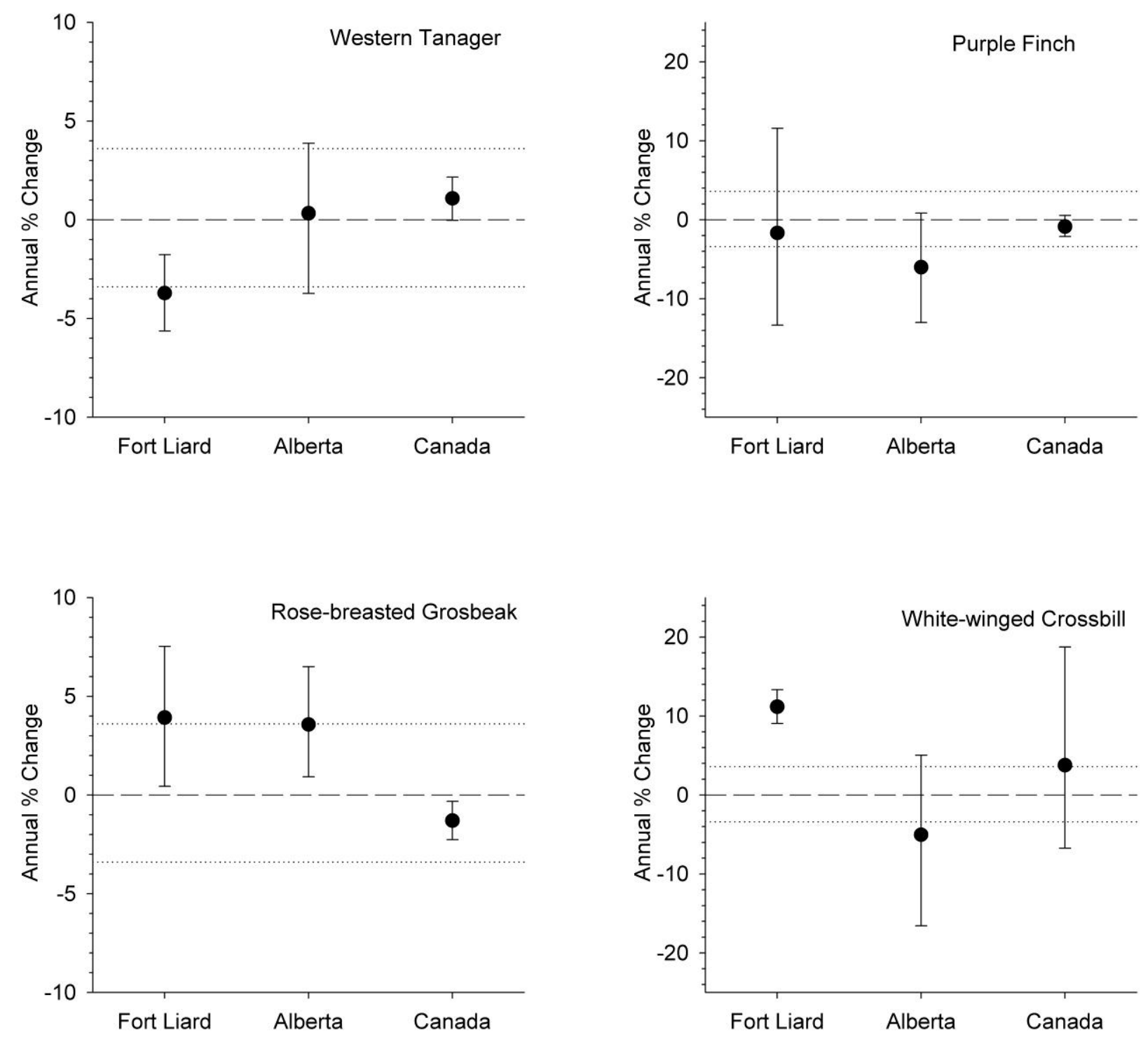

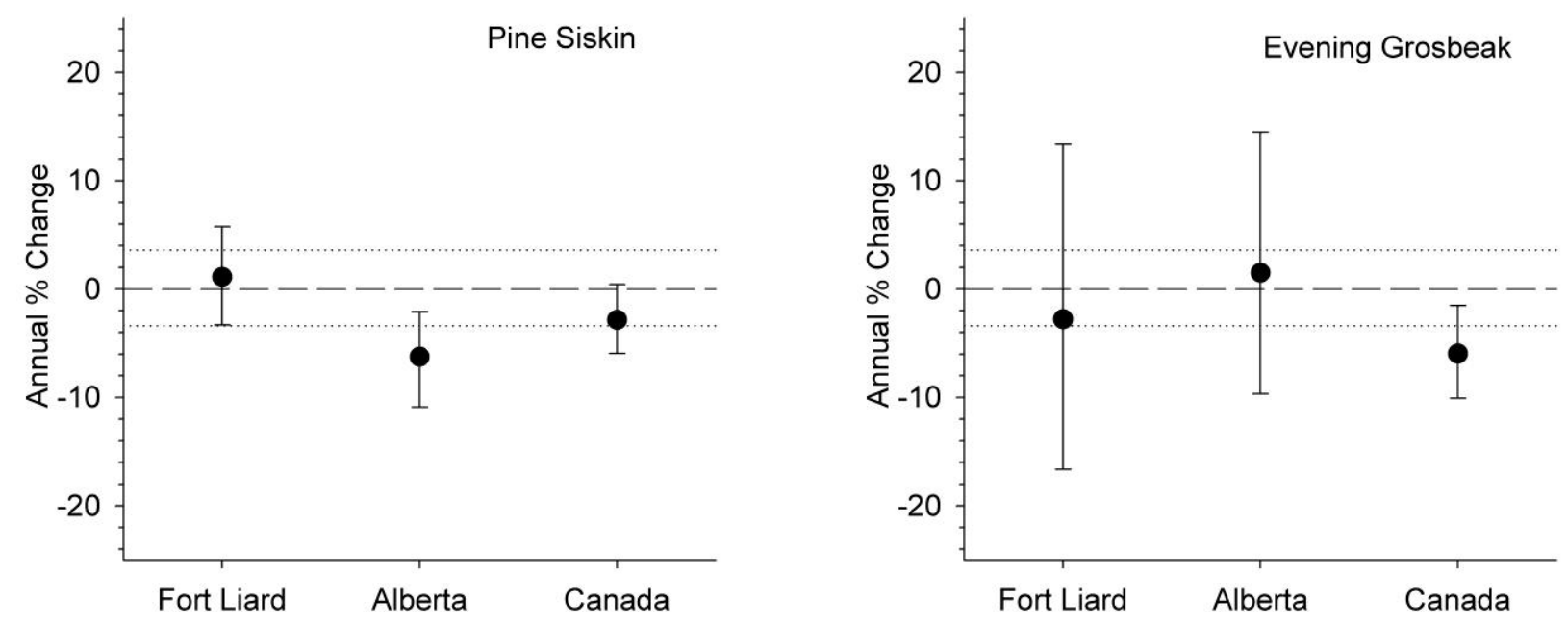